UNITED STATES DEPARTMENT OF THE INTERIOR

Harold L. Ickes, Secretary

GEOLOGICAL SURVEY

W. C. Mendenhall, Director

\title{
Bulletin 922-D
}

\section{CHROMITE DEPOSITS \\ OF GRANT COUNTY, OREGON}

\author{
A PRELIMINARY REPORT
}

BY

T. P. THAYER

Strategic Minerals Investigations, 1940 (Pages 75-113)

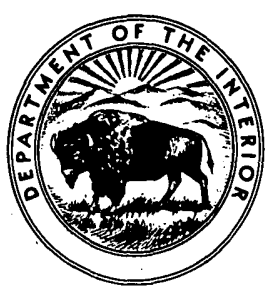

UNITED STATES

GOVERNMENT PRINTING OFFICE

WASHINGTON : 1940 



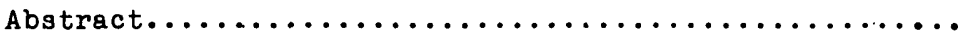

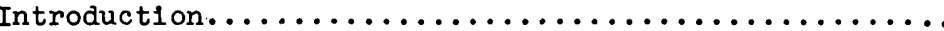

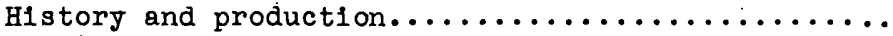

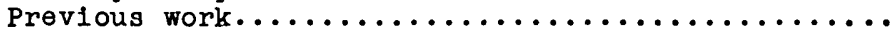

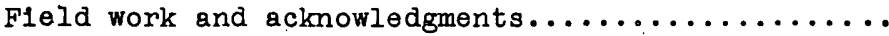

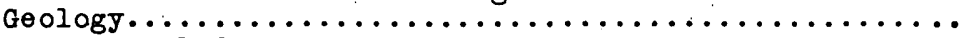

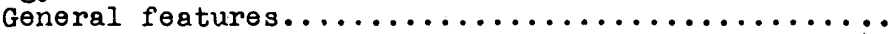

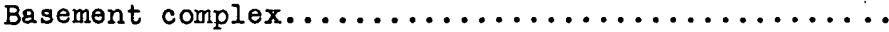

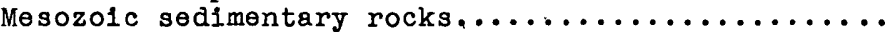

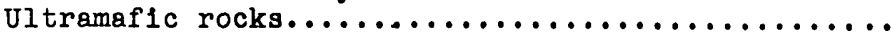

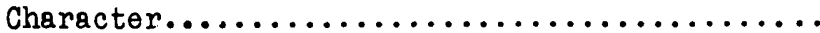

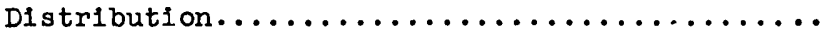

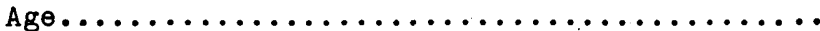

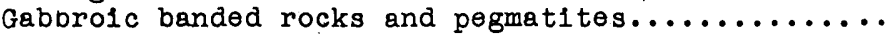
Tertiary and Quaternary rocks...............

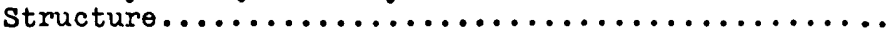

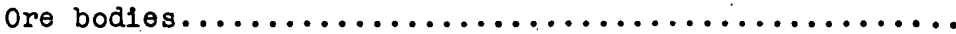

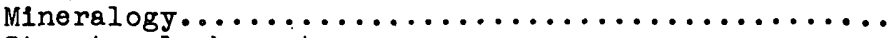

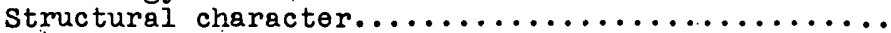

Relations of ore bodies to enclosing rocks........

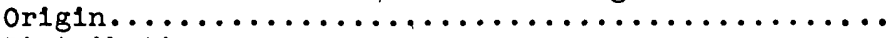

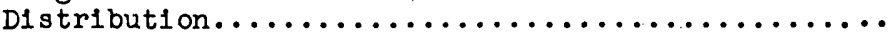

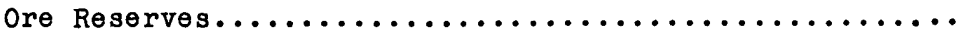

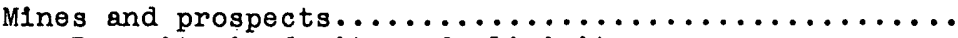

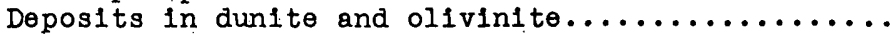

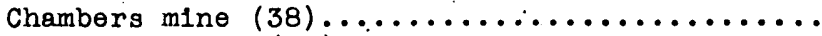

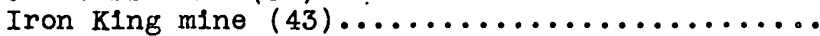

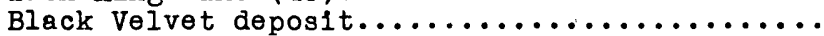

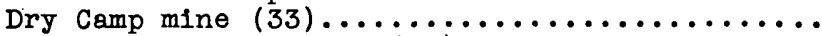

Marks \& Thompson mine $(27) \ldots \ldots \ldots \ldots \ldots \ldots$

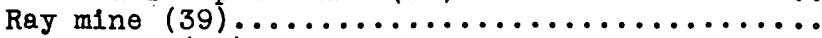

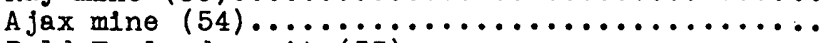

Bald Eagle deposit $(53) \ldots \ldots \ldots \ldots \ldots \ldots \ldots \ldots$

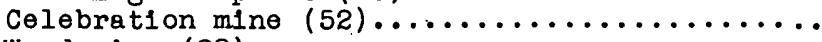

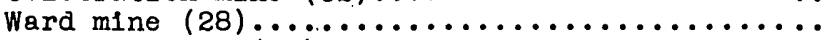

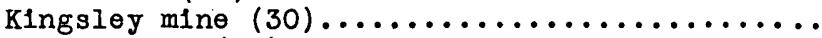

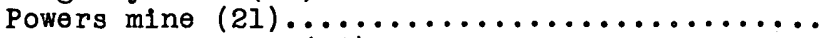

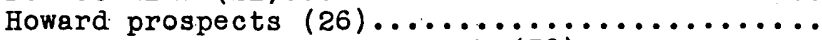

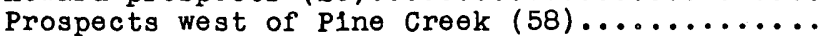

Sheөp Rock deposits $(37,40) \ldots \ldots \ldots \ldots \ldots \ldots \ldots$

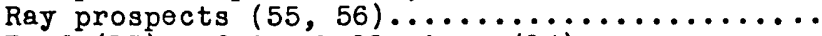

Reed $(13)$ and Campbell mines $(14) \ldots \ldots \ldots \ldots$

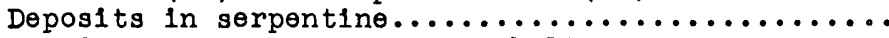

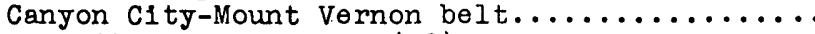

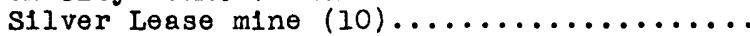

Norway (20) and Smith \& Geitsfield mines

(18) and prospect $(60) \ldots \ldots \ldots \ldots \ldots \ldots \ldots$

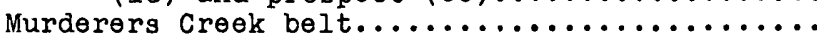

Glasscock clalms $(15,16,17) \ldots \ldots \ldots \ldots$

Hanking (Spring and Chrome Ridge) mine (45)

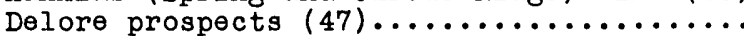

Prospects near Bull Spring (6I).......... 


\section{ILLUSTRATIONS}

Plate 12. Map of serpentine belts of Strawberry Range and chromite deposits of Grant County,

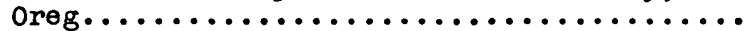

13. Preliminary geologic map of east half of Canyon city belt of ultramafic rocks, Grant County, Oreg................ In pocket

14. Geolog1c map of Chambers chromite deposit and sections through diamond drill holes.. 100

15. Geologic map and section of Iron King chromite deposit.................... 100

16. Vlew of quarry at Iron King mine......... 101

17. Geologic map and sections of Dry Camp chromite deposit................... In pocket

18. Geolog1c map of Marks \& Thompson chromite

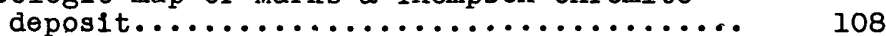

19. Plan of Ray mine.................. 108

20. Plan and section of Silver Lease chromite deposit......................... 109

Flgure 12. Specimen from dump of Ward mine showing relations between nodular ore, spotted ore, and barren duntte.................... 90

13. Superimposed linear and planar banding in

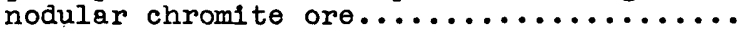

14. Plan of southwest end of southwest ore body

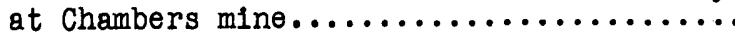

15. Plan of Black Velvet chromite deposit.......

17. Plan and section of Celebration mine........ 105

18. Plan of Ray chromite prospects between

overholt and Indian Creeks.............. 109

19. Plan of principal opening on Norway cla1m... 111 


\title{
CHROMITE DEPOSITS OF GRANT COUNTY, OREGON
}

\section{A PRELIMINARY REPORT}

\author{
By T. P. Thayer
}

\section{ABSTRACT}

The principal chromite deposits of Grant County, Oreg., occur in belts of peridotite and dunite, largely altered to serpentine, in the Strawberry Range. A few deposits have been found in the Greenhorn Mountains. The most productive mines are east of Canyon City in comparatively fresh unsheared ultramafic rocks in which the original mineralogic and textural characters are well-preserved. The borders of the mass are pyroxenltic, and the chrome deposits occur as irregular lenses in the less pyroxenitic and more dunitic central portion. The chromite appears to be genetically related to dunite and is probably of early magmatic origin. Most of the readily accessible deposits of high-grade chromite have been worked out, and future production will be predominantly from low-grade concentrating ore containing from 15 to 30 percent of chromic oxide $\left(\mathrm{Cr}_{2} \mathrm{O}_{3}\right)$. The known reserve in the explored deposits is about 80,000 tons of ore averaging between 20 and 35 percent of chromic oxide. With sufficientiy high prices, probably 200,000 tons of concentrating ore averaging between 20 and 25 percent of chromic oxide could be mined from the explored deposits in Grant county.

\section{INTRODUCTION}

The principal chromite deposits of this region occur in the Strawberry Range, in the south half of Grant County. Chromite has also been mined in the Greenhorn Mountains, which occupy the northeastern part of Grant County and the western edge of Baker County. The deposits in the Strawberry Range are described in this report. 
The Strawberry Range extends eastward for about 50 miles, connecting the Ochoco Mountains on the west with the Blue Mountains on the east. The principal peaks of the range are between 7,000 and 9,100 feet in alt1tude. The chromite deposits and the topographic and geologic relations between the range and the John Day River Valley to the north are shown on plates 12 and 13. The distance from John Day, the commercial center of the district, to Baker, on the Union Pacific Railroad, is 96 miles via the John Day Highway. The distance to Portland is 300 miles by paved highway. The nearest shlpping point is Seneca, 22 miles south of John Day, the terminus of the oregon \& Northwestern Rallroad, which connects with the Oregon Short Line at Burns, oreg. Ore shipped during 1917 and 1918 went from Prairle Clty, 13 mlies east of John Day, to Baker, via the narrow gage Sumpter Valley Railroad, where it was transferred to the Union Pacific Rallroad. The chromite deposits in the Greenhorn Mountains are served by mountain roads from Whitney and Sumpter, towns on the sumpter Valley Rallroad. In winter snow and mud render the roads Impassable for heavy trucks.

\section{History and production}

Occurrence of chromite in the strawberry. Range was mentioned by Lindgren in 1901. I/ Mining of chrome ore began in 1916 under the stimulus of high war-time prices, and shipments of 225 tons were made in January 1917. Total shipments of ore amounted to about 3,700 tons in 1917 and about 13,600 tons in 1918. $2 /$ Mining ceased when the war ended, and little ore was

1/ Lindgren, Waldemar, The gold belt of the Blue Nountains of Oregon:

U. S. Geol. Survey 22d Ann.-Rept., pt. 2, p. 713, 1901.

2/ Westgate, I. G., Deposits of chromite in northeastern Oregon:

J. S. Geol. Survey Bull. 725, p. 60, 1921. 
shipped thereafter. The total production of Grant County to 1925 was estimated by Furness 3 at about 20,000 tons. During November and December 1939 about 100 tons of ore was shipped from the Dry Camp mine for concentration tests.

\section{Previous work}

The report on the gold belt of the Blue Mountains by Lindgren, published in 1901, includes the most comprehensive account of the general geology of the Strawberry Range. Westgate 5 examined the chrome deposits in 1918, while mining was most active, and his report contains much information on workings that are now caved and inaccessible. Allen, in a report published in 1938, described the princlpal chromite deposits of northeastern oregon.

\section{Field work and acknowledgments}

This report is based on field work done by the writer between September 1 and December 10, 1939, w1th the assistance of P. W. Gulld, Darw1n Jepsen, and W. G. Lundstrum. The eastern part of the canyon city chromite belt was mapped on a scale of 2,000 feet to the inch. The larger chromite deposits were mapped on a scale of 40 feet to the Inch, with tape and plane table.

While the Geological Survey party was in the fleld, the United States Bureau of Mines explored and sampled the Chambers, Dry Camp, and Iron King deposits. Interpretation of the subsurface geology of these deposits is based largely on informa-

3/ Furness, J. W. , Chromite in 1925: U. S. Bur. Mines, Mineral Resources U. S., 1925, pt. 1, p. 141, 1928.

4/ Ilndgren, Weldemar, op. c1t., pp. 712-717.

5/ Westgate, I. G., op. clt:

$6 /$ Allen, J. E., Chromite deposits in Oregon: Oregon Dept. Geology and Min. Ind. Bull. 9, pp. 53-69, 1938. 
tion thus obtained, for which the writer is indebted to Mr. 0. H. Metzger, of the Bureau of Mines. Thanks are due also to the many local residents who supplied much information and served as guides.

\section{GEOLOGY}

\section{General features}

The oldest rocks of the district are schists and layered diorite, which will be referred to collectively as the basement complex. They are of Paleozolc age or older. The Mesozolc rocks, which consist mainly of sandstone, shale, chert, and limestone, contain some pebbly beds whose composition indicates that they were formed, at least in part, by erosion of the basement complex. Peridotite and dunite, partly altered to serpentine, are intrusive into both the basement complex and the Mesozolc rocks. They occur in two main belts (see pl. 12), one of them near Canyon City and the other from 15 to 20 miles southwest of 1t. The chromite occurs in the peridotite and dunlte. Tertiary lavas, tuffs, and conglomerates are widely distributed in the region surrounding the Strawberry Range. The area between the north base of the range and the John Day River is occupled by coalescing alluvial fans, which contain placer gold in the vicinity of canyon city. Some fairly extensive areas of alluvium and some glacial deposits lie within the range (see pl. 13).

\section{Basement complex}

The basement complex consists mainly of hornblendic greenstone schist and of gnelssic diorite or gabbro; it also includes some mica schist and quartzite. The rocks of the complex are the most resistant to erosion in the district. They occupy the higher part of the Strawberry Range, from Canyon Mountain to 
the foot of Strawberry Mountain, and small blocks of the complex in the ultramafic rocks commonly stand out in relief. The best exposure of the complex is in the bold cliffs forming the west face of Canyon Mountain. The greenstones and schists are readily distinguished from the ultramafic rocks by their schistose character. The dioritic rocks may be recognized by their abundant feldspar and also, in places, by the presence of pegmatite dikes containing a large proportion of black hornblende.

\section{Mesozolc sedimentary rocks}

Between Canyon Creek and Fields Creek, the Strawberry Range is made up almost wholly of highly: deformed sedimentary strata. The sediments consist mainly of well-bedded dark-gray sandstones, shales, siliceous siltstones, and chert. Some altered lavas and tuffs alternate with the sediments. Ilmestone occurs sporadically in small lenses. Fossils obtained from limestone west of Flelds Creek were Identified by Mr. G. A. Cooper, of the U. S. National Museum, as certainly Triassic, and probably Upper Triassic, in age. 7 . L. Lupher has mapped Triassic and Jurassic rocks in the southern slopes of the Strawberry Range, and probably rocks of both ages are present in the area west of Canyon Creek. Unlike the crystalline rocks of the basement complex, the Mesozolc sediments are practically unmetamorphosed, except near the contacts of intrusive masses.

\section{Ultramafic rocks}

\section{Character}

The chromium ores of this district, and of nearly all other districts in the world, are all contained in intrusive igneous rocks that are collectively classed as ultramafic. The term

7/ Written communication from J. B. Reeside, Jr., Feb. 7, 1940.

8) Personal communication, September 1939.

$2433280-40-2$ 
"ultramafic" was coined not many years ago as a substitute for "ultrabasic," which was regarded as inappropriate. Ultramafic implies, essentialiy, a high proportion of magnesium and iron. The chief original minerals that constitute ultramafic rocks are olivine and pyroxene, and the commonest accessory minerals are magnetite and chromite. The olivine, and to a less extent the pyroxene, are readily altered to minerals of the serpentine group. Rocks in which this alteration has been complete or nearly so are commonly called serpentine, and even where the alteration is only moderately advanced the resulting rock is often rather loosely called serpentine. In conformity with this popular usage, the ultramafic rocks are collectively desIgnated serpentine on plate 12.

The ultramafic rocks of Grant County are divisible into four intergrading kinds, according to the proportions in which olivine and pyroxene were originally present. These are: (1) Dunite, consisting almost wholly of olivine, with not more than 5 percent of pyroxene; (2) olivinite, containing 5 to 50 percent of pyroxene; (3) peridotite, containing 50 to 95 percent of pyroxene; (4) pyroxenite, containing 95 percent or more of pyroxene.

It is impracticable to follow this classification strictly in mapping (see pl. 13). The dunite and ollvinite that are not extremely altered are broadly distinguished from each other and from the more pyroxenic rocks, though the exact position of the boundary between intergrading rocks must obviously be uncertain in places. In many places, however, it is so difficult to distinguish peridotite from pyroxent te that these two rocks are mapped together. In large areas, moreover, the process of serpentinization has gone so far as to render uncertain the composition of the original rock; such areas are mapped as serpentine. 
The average composition of the ultramafic body as a whole is probably about that of olivinite containing 25 percent of pyroxene. Although specks of chromite occur throughout all the ultramafic rocks, almost all the workable chromite deposits occur in dunite or olivinite.

The dunite is a dense uniform rock in which no minerals stand out. Weathered surfaces are smooth and reddish brown to buff, and 1t is from this characteristic that the miners! term "buckskin" originated. Platy jointing is very common in the dunite. As a result of this jolnting and of low resistance to weathering, areas underlain by dunite are mostly covered with. a mantle of loose chips, and bedrock is rarely exposed.

0l1vinite and peridotite are red or brown to buff on weathered surfaces, are characterized by pyroxene grains that stand out in relief from the olivine matrix, and are readily identifled by their consplcuous cleavage. Outcrops of these rocks are scarce on gentle timbered slopes but are almost continuously exposed on the preclpitous walls of some of the canyons.

The pyroxenlte is very tough and resistant to weathering. Weathered surfaces are light green to brown and are roughened by projecting pyroxene crystals ranging from a quarter of an Inch to $1 \frac{1}{8}$ inches in length. In places the rock resembles a compact mass of wood chips. As pyroxenite occurs mainly in lenses rather than large homogeneous masses, 1ts outcrops assume the form of reefs that commonily stand 10 to 20 feet high.

Nearly all of the ultramaflc rocks are partly altered to serpentine, even though some of the pyroxenite appears fresh in hand specimen. The freshest-appearing dunite is now at least half serpentinized. In certain places alteration has gone so far that the original texture and composition are no longer recognizable in the fleld, and the rock can be mapped only as serpentine. That the serpentine is secondary is manifested by 
the complete gradations between serpentine and the least-altered rocks. The typical serpentine is medium to dark green or greenish black, soft, and broken by innumerable shear surfaces. This rock commonly forms smooth bare exposures that can be recognized from a considerable distance by their greenish colors and shiny slickensided surfaces.

Although possibly half of the ultramafic rocks are massive and apparently structureless, banding is prominent in a large part of them. The banding may express elther: (1) a layered structure revealed by unequal proportions of pyroxene and ol1vine in alternating rock layers, or (2) a linear structure shown by alinement of pyroxene crystals in an otherwise uniform rock. The first type of banding is illustrated by alternation of layers of olivinite and pyroxenite, but it may involve almost any combination of ultramafic rock types. The contacts between layers are gradational, but the layers are more or less distinct, especially where contrasting rock types are involved. In a given exposure, the adjolning bands may range in width from about an inch to several feet; lajering on a major scale gives rise to mappable bodies tens of feet wide and hundreds of feet long. The second type of banding is generally less prominent and even obscure, because the pyroxenes are arranged in discontinuous strings and there is no clear-cut alternation of different materials. Where the two types of banding occur together they are parallel. Linear structure, or arrangement of pyroxene and chromite grains in lines rather than planes, was noted in several places. This type of structure is well shown in several chromite deposits.

The attitude of the banding varies greatly from place to place, apparently without any system, over the district as a whole. In some areas, such as the upper drainage basin of Dog Creek, the dip and strike of banding varies only a few degrees over a square mile or more, but such consistency is rare. 


\section{Distribution}

The ultramafic rocks are best preserved in the eastern half of the Canyon City belt, east of Canyon Creek. In the westerm half of the canyon Clty belt and in the western or Murderers Creek belt the chromite-bearing rocks have been converted almost entirely to green serpentine. In the northeastern part of Grant County the chromite-bearing rocks are sheared green serpentine and talc-dolomite rocks that become yellow on weathering.

East of Canyon Creek the borders of the ultramafic belt are markedly pyroxenic. The general areal relations of pyroxentte and peridotite to olivinite and dunite are best exemplified in Byram Gulch, northwest of Canyon Mountain (pl. 13). There the border of peridotite and the central portion of dunite-olivinIte are unusually well developed and distinct. The intrusive contact with the basement complex is exposed in many places, and the transition zone between dunite and peridotite is only a few feet wide. Farther east the peridotite does not form a solid border but consists of a great number of peridotite and pyroxenite lenses orlented paraliel to the contact and enclosed in olivinite. The entire mapped portion of the southerm border zone also contains numerous tabular blocks of basement complex. The relations along the northern margin of the ultramafic mass are partly concealed by overlapping Tertiary rocks, and even where exposed they are obscured by extensive serpentinization and faulting. Blocks of Mesozolc (?) sediments and basement complex, however, are abundant. 


\section{Age}

The fossiliferous limestone west of Fields Creek lies in chert and argillite about 125 feet from the serpentine contact and is older than the serpentine. Lupher $9 /$ states that the serpentine in the silvies River district south of Seneca is intruded. Into fossiliferous Upper Triassic IImestone and is unconformably overlain by fossiliferous Lower Jurassic limestone. The serpentine and ultramafic rocks of the strawberry Range are accordingly regarded as of Triassic age or younger.

\section{Gabbrolc banded rocks and pegmatites}

Some" chromite bodies, notably those at the Chambers mine, are cut by dikes of coarse pegmatite and medium to fine-grained gabbro. The known width of the dikes is between one-fourth Inch and 1 foot, and diamond drill holes at the Chambers mine penetrated as much as 6 feet of gabbro between chromite walls. The feldspar in the pegmatite is calcic bytownite, and the pegmatite grades into the gabbro. Small exposures of banded gabbro are fairly common in the olivinite in the vicinity of the Chambers and Bald Eagle mines. These gabbrolc bands are undoubtedly closely related to a banded complex of ultramafic rocks and gabbro that is exposed for a distance of about a mile along the ridge extending south from Bald Mountain. Some of the banded gabbro resembles parts of the basement complex. The Celebration mine is in a dunite band included in the gabbro complex, and other chromite deposits may be present, although none have come to the writer's attention. The gabbro seems to have been affected by the same agencles that serpen-

9/ Lupher, R. L., personal communication, September 1939. 


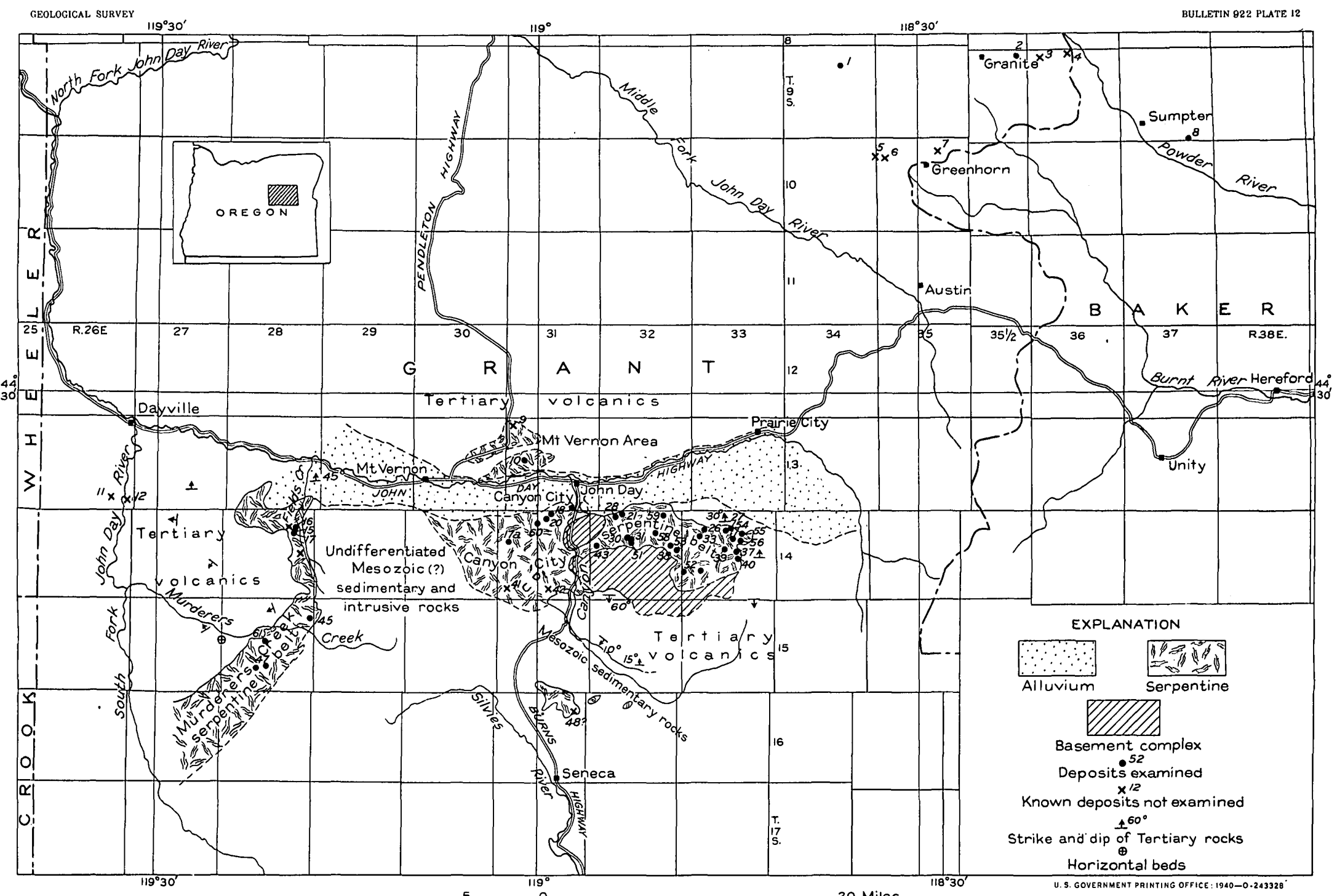

MAP OF THE SERPENTINE BELTS OF THE STRAWBERRY RANGE AND THE CHROMITE DEPOSITS OF GRANT COUNTY, OREG. The numbers refer to deposits described in the text or in earlier reports 
tinized the ultramafic rocks, and therefore probably antedates the serpentinization and is of about the same age as the ultramafic rocks--Triassic or younger.

\section{Tertiary and Quaternary rocks}

The oldest Tertiary deposits of the John Day district are conglomerates several hundred feet thick, whlch lie unconformably on the older rocks and were in part derlved from them. The age of these conglomerates is not definitely known. The conglomerates are overlain by successive basalt flows several hundred feet thick, which are probably equivalent in age to the Columbia River basalt. 'In the vicinity of Mount Vernon, tuff of the Pliocene Rattlesnake formation is well-exposed and lies unconformably across the edges of the lower basalts.: East of John Day and north of the John Day River, an upper serles of basalt flows lies on pumiceous water-la1d tuff that is probably part of the Rattlesnake formation. Volcanic rocks are wellexposed In Strawberry Mountain, in the valley of Berry Creek south of Canyon Mountain, and in the vicinity of Fields Creek.

East of Canyon Creek and south of the John Day RIver, the volcanics are burled under broad alluvial fans bullt out from the north base of the mountains. The largest fans were built by the creeks that drain the high parts of the range and whose headwaters bear unmistakable evidence of glaclation. The Little Pine Creek fan and the debris shed from Little Canyon Mountain contain placer gold that has been mined on a large scale. The present valley of the John Day River is cut along the outer edge of the old fans, and the alluvium of the valley floor is the latest deposit of the region. Down cutting by the John Day River and its tributarles left the old placer deposits perched 200 feet or more above the present stream beds. 


\section{$\underline{\text { Structure }}$}

The Strawberry Range is eroded from an east-west anticline between the John Day syncline on the north and the broad structural basin of Bear Valley on the south. The range is an easterly extension of the ochoco Mountain uplift, although it is topographlcally separated from the ochoco Mountains by the valley of the South Fork of the John Day River. East of Strawberry Mountain the anticline flattens and merges into the southeastern end of the Greenhorn Mountains. East of Canyon Creek the Strawberry Range anticline is symmetrical, and the dips in the Tertlary rocks on both flanks are between $30^{\circ}$ and $60^{\circ}$. Between Canyon and Fielas Creeks the anticline is markedly asymmetrical, the north limb dipping $30^{\circ}$ to $45^{\circ}$ and the south limb probably $5^{\circ}$ to $10^{\circ}$. The transition zone between the symmetrical and asymmetrical parts of the anticline lies just west of Canyon Creek.

Although the structure of the pre-Triassic schists is very complex, and their contacts with the dioritic rocks are intricate, the structure of the dioritic rocks themselves is relatively simple. The deformation of these intmusive rocks is mainly shown by a persistent banding, the strike of which ranges from N. $65^{\circ}$ W. to N. $85^{\circ}$ E. and the dip from $65^{\circ} \mathrm{N}$. to $65^{\circ} \mathrm{S}$.

The contacts of the ultramaflc intrusives with older rocks have been studied most thoroughly in the belt east of Canyon Creek, which is bounded on the south by the basement complex and on the north mainly by Mesozolc sediments. These contacts are everywhere nearly vertical. Their details are so complex as to be hard to decipher or to represent on even a large-scale map. The main mass has many offshoots extending into the older rocks, and it contains many inclusions of these rocks near the main contacts. In the valley of canjon Creek the belt of ultra- 
mafic intrusives abruptly broadens and cuts of the basement complex, and at its western end it frays out into a series of lenses in the Mesozoic sedimentary rocks. The serpentine northeast of Mount Vernon was intruded into Mesozolc sedimentary rocks and may be a continuation of the Canyon City serpentine belt under the alluvium of the John Day Valley.

The Murderers Creek serpentine belt consists of several serpentine lenses trending north or northeast in the Mesozo1c sedimentary rocks. It is overlapped on the west side by Tertiary lavas. The east limit of the belt is indefinite, and small serpentine lenses are known to occur in the area to the east where the Tertiary cover has been removed.

ORE BODIES

Workable chromite deposits occur as rather well defined Irregular lenticular bodies seattered haphazardy in the ollvinitic and dunftic parts of the ultramafic belt. The ore bodies range from deposits of a few pounds to those of several thousand tons, though relatively few of them contain more than 100 tons.

\section{Mineralogy}

The essential constituent of chrome deposits is the mineral chromite, which is easily scratched with a knife blade, forms a brown powder, and ordinarily is not attracted by a hand magnet. Theoretically pure chromite contains 68 percent of chromic oxide $\left(\mathrm{Cr}_{2} \mathrm{O}_{3}\right)$ and 32 percent of ferrous oxide ( $\left.\mathrm{FeO}\right)$. In most chromite alumina $\left(\mathrm{Al}_{2} \mathrm{O}_{3}\right)$ and ferric oxide $\left(\mathrm{Fe}_{2} \mathrm{O}_{3}\right)$ replace part of the chromic oxlde and magnesia (MgO) replaces part of the ferrous iron, so that the actual chrome content is far less $2433280-40-3$ 
than the theoretical maximum. The following analyses, made in the chemical laboratory of the United States Geological Survey, indicate that the chrome content for deposits in Grant county ranges from 34 to 52 percent.

Partial analyses of chromite from Grant County, Oreg. [R. C. Wells, analyst]

\begin{tabular}{c|c|c|c|c|c}
\hline \multirow{2}{*}{ Depos1t } & \multirow{2}{*}{$\begin{array}{c}\text { Type of ore } \\
\text { sample }\end{array}$} & $\begin{array}{c}\text { Concentrate in } \\
\text { total sample } \\
\text { (percent) }\end{array}$ & \multicolumn{2}{|c|}{ Analysis of concentrate } \\
\cline { 5 - 6 } & & $\begin{array}{c}\text { Cr2 } 3 \\
\text { (percent) }\end{array}$ & $\begin{array}{c}\text { Fe } \\
\text { (percent) }\end{array}$ & Cr/Fe \\
\hline Dry Camp.. & Massive... & 82.8 & 51.6 & 12.7 & 2.77 \\
Iron King. & Spotted... & 60.6 & 42.0 & 13.9 & 2.06 \\
Chambers.. & Massive... & 81.8 & 37.8 & 11.9 & 2.16 \\
A jax...... & Nodular... & 46.8 & 37.6 & 14.1 & 1.83 \\
Bald Eagle & ....do.... & 50.1 & 34.3 & 12.6 & 1.86 \\
Delore 1/ & Massive... & 19.2 & 43.2 & 21.1 & 1.40 \\
Do.2f... & ....do.... & 78.1 & 41.1 & 21.0 & 1.33 \\
\hline
\end{tabular}

1/ Moderately magnetic fraction.

2/ Weakly magnetic fraction.

Complete analyses have been made of only two specimens.

\section{Complete analyses of chromite concentrates} from Grant county, Oreg.

$[\bar{R}$. C. Wells, analyst

\begin{tabular}{|c|c|c|c|c|c|}
\hline & 1 & 2 & & 1 & 2 \\
\hline $\mathrm{S} \mathrm{O}_{2} \ldots \ldots \ldots$ & 1.9 & 2.8 & $\mathrm{~T}^{10_{2}} \ldots \ldots$ & 0.3 & 0.2 \\
\hline $\mathrm{Al}_{2} \mathrm{O}_{3} \ldots \ldots$ & 27.0 & 13.3 & $\mathrm{Cr}_{2} \mathrm{O}_{3} \ldots$ & 37.8 & 51.6 \\
\hline $\mathrm{Fe}_{2} \mathrm{O}_{3} \ldots$ & .8 & None & MnO. & Trace & .3 \\
\hline $\mathrm{Fe} 0 \ldots \ldots \ldots$ & 14.6 & 16.4 & $\mathrm{H}_{2} \mathrm{O} \ldots \ldots \ldots$ & .3 & 1.3 \\
\hline $\begin{array}{l}\mathrm{Mg} 0 \ldots \ldots \ldots \ldots \\
\mathrm{C} g 0 \ldots \ldots \ldots \ldots\end{array}$ & $\begin{array}{r}15.2 \\
.3\end{array}$ & $\begin{array}{r}23.4 \\
.1\end{array}$ & & 97.9 & $\overline{99.4}$ \\
\hline
\end{tabular}

1. Massive ore from Chambers mine.

2. Massive ore from Dry Camp mine.

The analyses show that the chrome content of the chromite is variable and that it is not the same in any two deposits. This variation is of great economic importance, as the grade of any concentrate mechanically produced depends directly upon the purity of the ore-bearing mineral in the concentrate; for example, concentrates contalning 50 percent of chromic oxide could probably be obtained commercially from the Dry Camp deposit, whereas concentrates from the Bald Eagle deposit might 
contain only 33 percent of chromic oxide. It is also obvious that bulk samples of spotted ore from the Dry Camp deposit and of massive ore from the Chambers deposit might give similar assays. Therefore assays of channel samples can give only partial information as to the real value of a deposit. Complete sampling procedure entalls concentration of the channel samples with determination of the ratio of concentration of each and assays of enough of the concentrates to determine thelr average chromic oxide content.

The size of the chromite grains in spotted ore affects the degree of grinding necessary to free the ore from the gangue. Chromite crushes readily, and in fine grinding the loss caused by sliming is appreciable. The chromite grains in most of the deposits in Grant County are more than $1 \mathrm{~mm}$. In diameter, and fine grinding is probably not necessary. In the Iron King depos1t, however, the chromite grains average 0.2 to $0.5 \mathrm{~mm}$. across, and loss due to sliming during the necessary fine grinding may be excessive.

In most deposits the matrix of the ore is serpentinized dunite, and the difference in gravity between chromite and gangue is great enough to permit concentration by gravity methods. All the ore contalns some gangue, and there are all gradations from massive chromite to scattered chromite grains in dunite. The contrast between green or brown serpentine and specks or grains of black chromite gives most of the ore a spotted appearance. Chromite crystals are rare in the Grant County deposits, and in most of the spotted ore the chromite grains are angular or rounded. In a few deposits the chromite forms ellipsoldal globules from a quarter to an inch in diameter; this type of chromite, 11lustrated in flgure 12, const1tutes the so-called nodular ore. The chromite specimens shown 
In figures 12 and 13 were so treated and photographed as to obtain maximum contrast between serpentine and chromite. Where the serpentine was dark and failed to give good contrast, the specimen was treated with hydrofluoric acid, which etches and whitens the serpentine but does not attack the chromite.

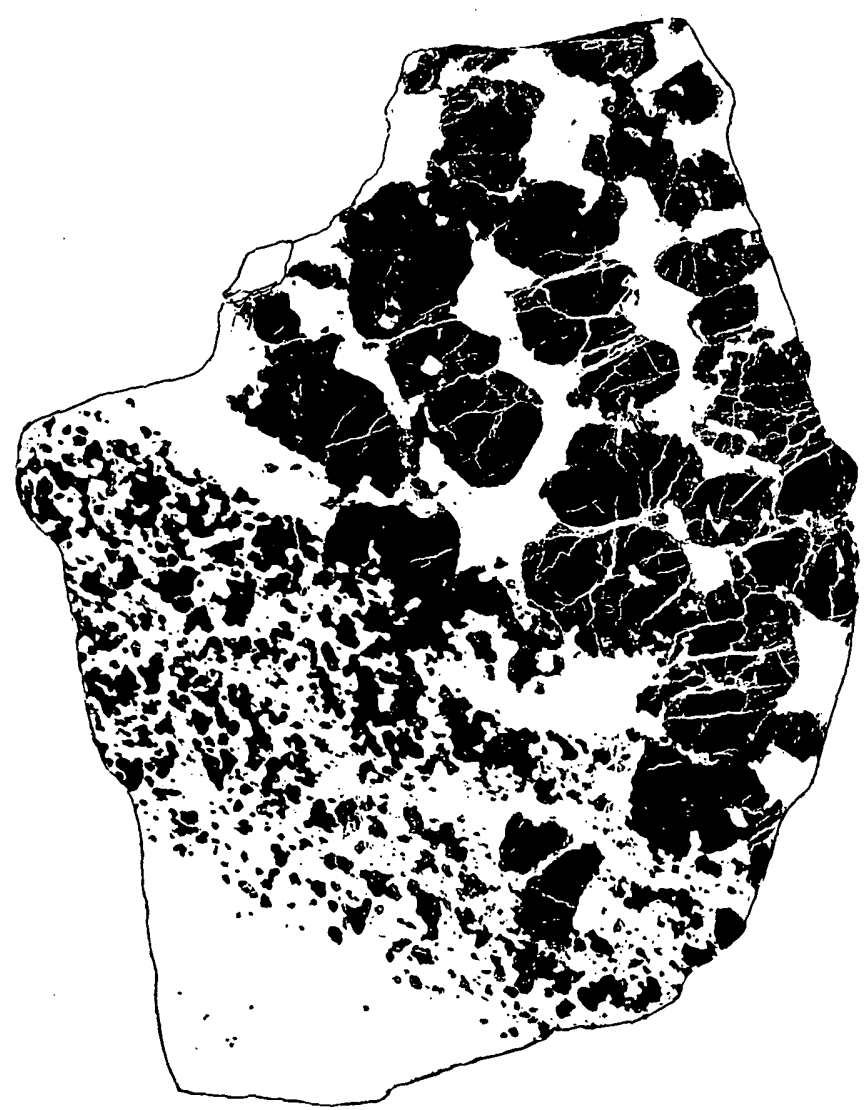

Figure 12.--Specimen from dump of Ward mine showing relations between nodular ore, spotted ore, and barren dunite.

\section{Structural character}

Banding is developed to some degree in nearly all the chromite deposits. In most of the deposits only one type of banding, either planar or linear, is shown, but in a few places, as for example the Iron King mine, linear banding is superimposed on planar banding. 
Linear banding is well-shown in the Big Bertha deposit, where the ore shows marked vertical stripes in two adjacent walls of the prospect pit yet appears evenly disseminated in the floor. In the Afax deposit the chromite aggregates are arranged like beads on strings, and some appear as flattened
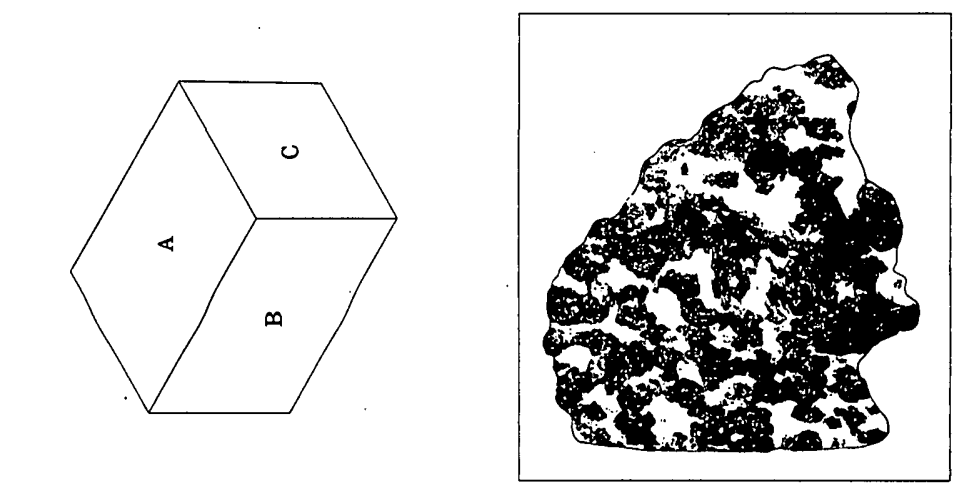

c.
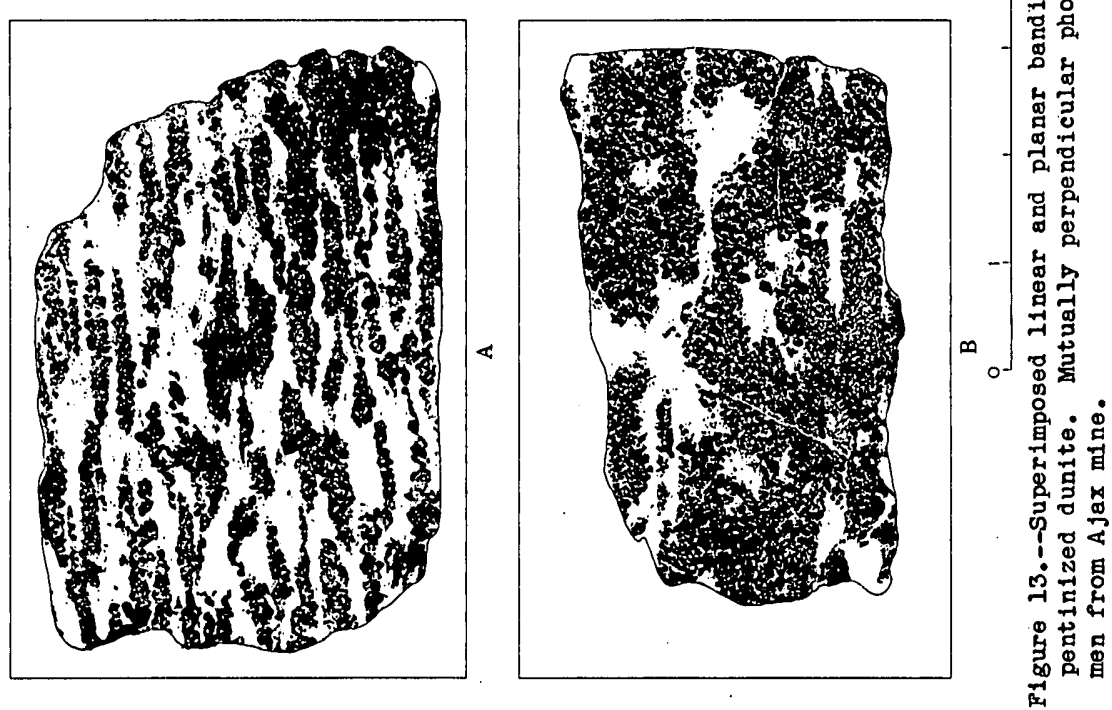

torpedo-shaped masses; this flattening of the chromite nodules extends along parallel planes and constitutes an obscure planar banding (f1g. 13).

Planar banding, or alternation of layers of high- and lowgrade ore, is best shown at the Dry Camp deposit, where massive chromite occurs in layers from a quarter of an inch to 2 inches 
in thickness. The chromite of the thinnest layers occurs in closely spaced grains or in irregular tabular masses such as might be formed by stretching of a thin, brittle sheet. In deposits devold of massive ore the banding consists of alternatIng medium- or low-grade spotted ore and barren rock.

At the Iron King mine the major banding in the quarry face is planar, but ore specimens show prominent linear banding. The longitudinal axis of the linear banding is parallel to the planar banding, as it is wherever the two types of bands have been seen together.

Although zones of higher-grade ore can be mined selectively in deposits that show planar banding, the thinner individual bands cannot be sorted effectively by hand. Separation of ore and barren rock in deposits in which linear banding is dominant is especially difficult, because pipelike or torpedo-shaped masses of gangue occur in the ore, and cone-shaped masses of spotted ore extend out into the walls of the deposit.

\section{Relations of ore bodies to enclosing rocks}

The relations between the chromite bodies and the country rock of this region may be summarized. In the statement that the chromite is as truly a component of the ultramafic rocks as olivine and pyroxene, and its occurrence is governed by the same laws. Just as there are gradations between dunite and pyroxenite, so there are all gradations between massive chromite and dunite or olivinite. None of the commercial chromite bodies in the Strawberry Range occur in peridotite or pyroxenite. In some places, transition from good ore to virtually barren rock takes place within a few inches; in other places the transition is so gradual that the deposit, in mining parlance, has "assay walls." Where the deposit is bounded by faults, as is common where the country rock is sheared serpentine, the walls are likely to be definite. 
Banding in the chromite is generally parallel to the longer dimensions of the ore body and to the banding in the country rock. It cannot safely be assumed, however, that an ore body will extend far in the direction of banding, because ore may be cut off sharply across banding without faulting (fig. 14). Many small chromite deposits are merely irregular lumps of highgrade ore. The larger deposits are mainly irregular lenses whose long axes may plunge at angles between $15^{\circ}$ and $90^{\circ}$ in any direction.

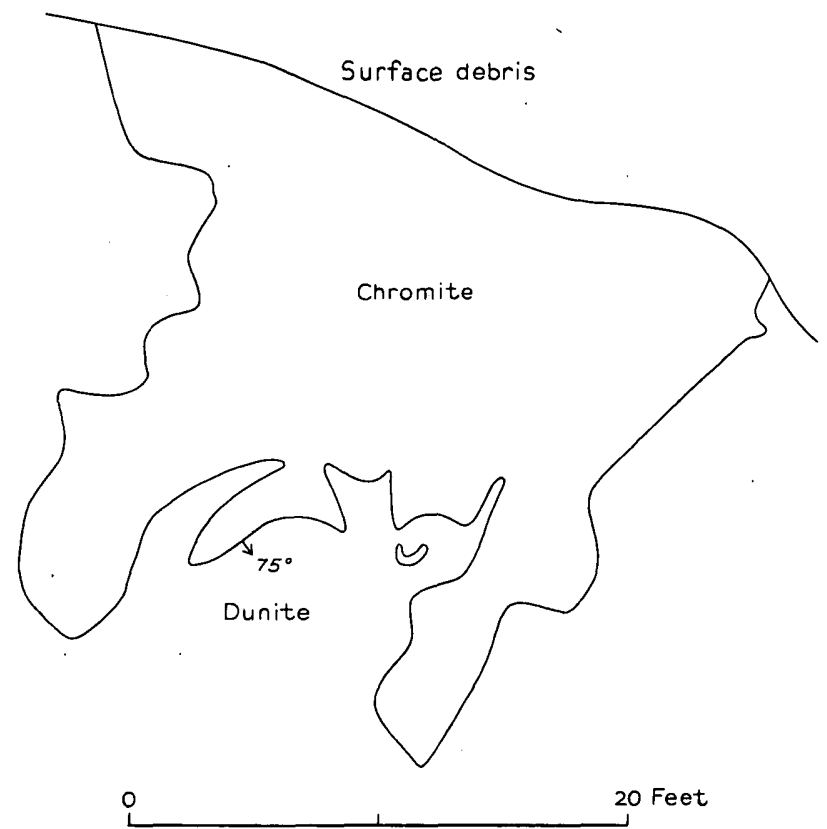

Figure 14.--Plan of southwest end of southwest ore body at Chambers mine showing irregularity of contact between chromite and dunite country rock. Except where dip is indicated the contact appears vertical.

The forms of the chromite bodies of this region are so irregular that estimates of ore reserves from surface exposures, even in well-banded deposits, must be made with great caution. The attitude and size of most of the bodies can be determined only by diamond drilling or actual mining operations. 


\section{Origin}

The chromite that occurs in bodies large enough to be of commercial interest is clearly of early magmatic origin. Massive chromite in the upper deposit at the Dry camp mine is cut by numerous fractures that are fllled with serpentine in which residual olivine pseudomorphs are preserved. Near the southwest end of the same deposit, the banded ore is cut by a dunite dike 2 inches thick. The relations between nodular and spotted ore in serpentinized dunite at the Ward mine (fig. 12) suggest that the spotted ore was formed by fragmentation of the nodular chromite as a result of flowage while the dunite magma was plastic. Remnants of olivine are here preserved in the serpentine, which shows unsheared mesh structure. The linear banding in deposits like the Ajax seems best explained by magmatic flowage that occurred after crystallization of the chromite and before solidification of the dunite.

\section{Distribution}

As the chromite bodies were formed by magmatic processes far below the surface, their relation to the present surface is entirely accidental. As chromite is very insoluble and resistant to surface weathering, secondary enrichment does not occur, and the chromic oxide content varies no more vertically than it does horizontally. The distribution of chrome lenses on the surface appears to be haphazard, like that of raisins in a pudding, and the same haphazard distribution probably holds in depth. Although an affinity between chromite and dunite is shown both by localization of chromite deposits in dunite lenses and by the dunitic character of the matrix of most of the chromite ore, some of the largest deposits occur in olivinite. 
In general, it seems that the edges of the ultramafic belt, where peridotite and pyroxenite prevail, are unfavorable areas for prospecting and that attention should be concentrated on the areas underlain by dunite and olivinite.

\section{ORE RESERVES}

The chromite deposits of Grant County probably cannot now compete with chromite from forelgn sources in present American markets. The known high-grade deposits are so small that mining costs are high. The large deposits are subcommercial in grade, and the minable product must be concentrated to be acceptable at any price in an open market, and transportation costs to present consuming centers are high. The only ore shipped from the district since 1920 was used solely for milling tests. However, the known deposits do constitute important reserves that would be usable in times of national emergency, when economic restrictions of grade and price would be relaxed.

From the figures quoted in Westgate's fleld notes, which contain data gathered from the mine owners and operators in August 1918, high-grade ore, containing more than 40 percent of chromic oxide $\left(\mathrm{Cr}_{2} \mathrm{O}_{3}\right)$, constituted about one-fourth of the t,otal ore shipped. Although only four mines produced 300 tons or more each of high-grade ore, about 90 percent of the total production of low-grade ore, which averaged about 32 percent of chromic oxide, came from three mines. In future shipments of crude ore from the district, the ratio of low-grade to highgrade ore will be greater than in the past, because most of the high-grade deposits exposed at the surface have been mined out.

Surface trenching and shallow diamond drilling of three deposits--Chambers, Iron King, and Dry Camp--by the Bureau of Mines Indicate between 80,000 and 130,000 tons of chrome ore 
averaging 25 percent of chromic oxide above the depth drilled. With sufficiently high prices and establishment of custom mills for concentrating low-grade ore, probably 200,000 tons of material averaging 25 percent of chromic oxide could be mined from known ore bodies.

\section{MINES AND PROSPECTS}

Nearly 100 chromite prospects are known in the area east of Canyon Creek alone. Only the more productive mines, the larger prospects, and the prospects in which the relations of chromite are unusually well shown will be described. Several deposits described by Westgate are here omitted elther because they were not visited or because the workings are inaccessible and no additional information was obtained. The reader is referred to Westgate 10 and Allen $11 /$ for descriptions of the deposits in the Greenhorn and Granite districts and of several mines in the Canyon City district which were not visited by the writer or which are now caved. Production figures for individual mines are quoted from Westgate's field notes or records of the United States Bureau of Mines.

\section{Deposits in dunite and olivinite}

Chambers mine (38) $12 /$.-The Chambers mine is at an altitude of about 6,500 feet on the northwest end of Bald Mountain, in the southeast corner of sec. 13, T. 14 S., R. $32 \mathrm{E}$. The mine is 13 miles by road from John Day, 8 miles of which is dirt road. Mining operations began in June 1918, and total

10/ Festgate, L. G., Deposits of chromite in eastern Oregon: $U_{.} \mathrm{S}$. Cool. Survey Bull. 725, pp. 37-60, 1921.

$11 /$ Allen, J. B., Chromite deposits in Oregon: Oregon Dept. Geology and M1n. Industr1es Bul1. 9, pp. 53-69, 1938. 12 Thubers in parentheses are those used on the map (pl, 12) and in the reports by Westgate and Allen. 
production was probably about 6,000 tons. The ore shipped averaged 30 to 33 percent of chromic oxide. All ore under 28 percent, which included about one-fourth of the total ore mined, was discarded. Practically all ore shipped was mined from the glory hole show on plate 14. The sample trenches and diamond drill holes were made by the Bureau of Mines.

The ore is mainly coarse spotted chromite in dunite that grades into massive chromite. In places it shows rude planar banding, best shown in the southwest ore body, where the bands dip about $70^{\circ} \mathrm{SE}$. The matrix of the ore is serpentinized dunIte, and, as shown in the cross sections, the ore bodies are almost surrounded by a shell of serpentinized dunlte. The ore grades abruptly into the dunite where the contacts are not faulted, and the dunite grades outward into olivinite. Even where the chromite is in frozen contact with olivinite the matrix, between the chromlte grains, is dunite. Small velns or dikes of green pyroxene from one-elghth of an inch to li inches wide are common. They are probably genetically related to the larger gabbro and gabbro pegmat1te dikes that cut the chromite in the glory hole. The pegmatite contains angular blocks of spotted chromite, and diamond drill hole No. 13 passed through about 10 feet of gabbro that cuts good ore. The gabbro is readily removed by hand sorting during mining. Many small faults cut the ore but thus far have not serlously interfered with mining operations.

Three major ore bodies and some smaller unworkable lenses are known on the Chambers ground. The size and general relations of the ore bodies are shown on plate 14. The southwest ore body is a lenticular mass dipping steeply southward and plunging northeastward. Most of the central ore body, which appears to be in the form of a short kidney, probably has been mined out. A tunnel, now caved, under the western edge of the 
glory hole was reported by Westgate to be in barren serpentine. Diamond drill holes Nos. 6 and 10 were barren, which indicates that the ore body does not extend to any great depth. The northeast ore body may consist of two overlapping lenses, but It seems more probably to be one large lens that has been faulted, for faulting at the edge of the ore is evident in cores from drill holes Nos, 12 and 16. Between drill holes Nos. 13 and 17 the ore either pinches out or is dropped along a fault parallel to the one indicated on plate 14. The average tenor of the ore, judged on the basis of past production and Bureau of Mines assays, is between 20 and 30 percent of chromic oxide.

Iron King mine (43).--The Iron King mine is at an altitude of 5,400 feet, in the SW $\frac{1}{4}$ sec. 18, T. 14 S., R. $32 \mathrm{E}$, , on the west slope of the northwest spur of Canyon Mountain. The mine

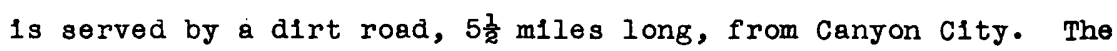
workings, which consist of an open quarry, a tunnel, and small open pits, are shown on plate 15.

Mining at the Iron King deposit began in 1916, and 500 tons of ore was shipped by the end of the year. About 3,000 tons was shipped annually during 1917 and 1918, making the total production approximately 6,500 tons. The ore was hand-sorted, and there are now several hundred tons of low-grade ore in the dump. The shipping ore averaged about 32 percent of chromic oxide.

The ore $\varepsilon t$ the Iron King mine is fine-grained spotted chromite in a matrix of serpentine derived from dunite. The ore is banded and gradatos all the way from massive black ore containing, acsording to Bureau of Mines analyses, about 43 percent of chromic oxide to barren serpentinized dunite. Although planar banding is most apparent in the quarry face, dump spec1mens show well-developed linear banding. The primary, magmatic 
character of the banding is still evident despite serpentinization and complex faulting. Mainly because of such complex faulting, the distribution of the ore, as shown on plate 16, is very irregular. The dunite mass in which the ore occurs is surrounded by ollvinlte in whlch irregular bodles of perldotite and pyroxenite occur. These pyroxenic masses are related to the pyroxen1c border facies of the ultramafic rocks, and about 200 feet south of the mine a large east-west block of gneissic basement complex is included in the olivinite. The main contact of the intrusive mass with the basement complex is about 1,600 feet south of the mine. Small velns of magnesite occur In the serpentine, and large crystals of aragonite occur in open fractures in the chromite.

The ore body in the Iron King deposit appears to be a nearly horizontal tabular mass, which is bounded laterally by faults and has been broken into several blocks that rise northward in a series of steps. The apparent dip of the banding in the individual fault blocks exposed in the quarry face is less than $15^{\circ} \mathrm{NW}$. or SW., the dips in adjoining blocks being commonly in opposite directions. The chromite is cut off on the west by a fault that strikes N. $40^{\circ}$ E. and dips $41^{\circ}$ SE. The footwall of this fault forms the west wall of the quarry and was penetrated at a depth of 56 feet in diamond drill hole No. 24. The southeastern edge of the ore body is faulted against sheared and slickensided serpentine in the quarry face, and the northeastern limit of the ore-bearing block is probably a fault that brings serpentinlzed dunite against peridotite and pyroxenite. Drill hole No. 29 reached the hanging wall of a breccla zone containing fragments of chromite ore at a depth of 63 feet, and from this fact and the surface exposures it is inferred that the fault trends about N. $50^{\circ} \mathrm{W}$. and dips $50^{\circ} \mathrm{NE}$. The small chrom1te blocks exposed southeast of the main ore body appear 
to be in the breccla, and the highest chromite exposure northwest of the quarry $110 \mathrm{~s}$ close to the northwesterly projection of the fault, on the footwall side. The intersection of the breccla zone with the footwall fault presumably determines the northwesternmost extension of the ore-bearing block. The total width of the ore in the quarry face is 115 feet, and the total exposed thickness ranges between 10 and 25 feet. The chromite exposed in the quarry floor is a thin band dipping $10^{\circ}$ or $15^{\circ}$ toward the quarry face. The tunnel east of the quarry is in barren serpentine, and no indications of minable ore were found southeast of the quarry or below the quarry level. The record of shipments indicates that the ore averages 25 to 30 percent of chromic oxide $\left(\mathrm{Cr}_{2} \mathrm{O}_{3}\right)$, Including low-grade ore thrown on the dump.

Black Velvet deposit.--The Black Velvet claim is about 750 feet nortbwest of the Iron KIng mine and 50 feet above the road. Flgure 15 shows the size and shape of the ore body. The ore is spotted chromite with planar banding that dips parallel to banding in the enclosing olivinite. At the north end the chromite pinches out. Along the fault in the northern trench the spotted chromite and serpentine have been ground to a streaked gray and brown massive rock that is fully as hard as the adjoining serpentinized olivinite. Elsewhere the contacts are gradational. Ore with a vertical thickness of 6 feet is exposed in the north trench, and the limlts of the body were falrly accurately located in small pits. The ore probably contains between 15 and 25 percent of chromic oxide.

Dry Camp mine (33).--The Dry Camp mine is in the southerm part of the SW sec. 8, T. 14 S., R. 33 E., a short distance east of Little Indian Creek. The deposit is $7 \frac{1}{2}$ miles by dirt road from the John Day Highway. 


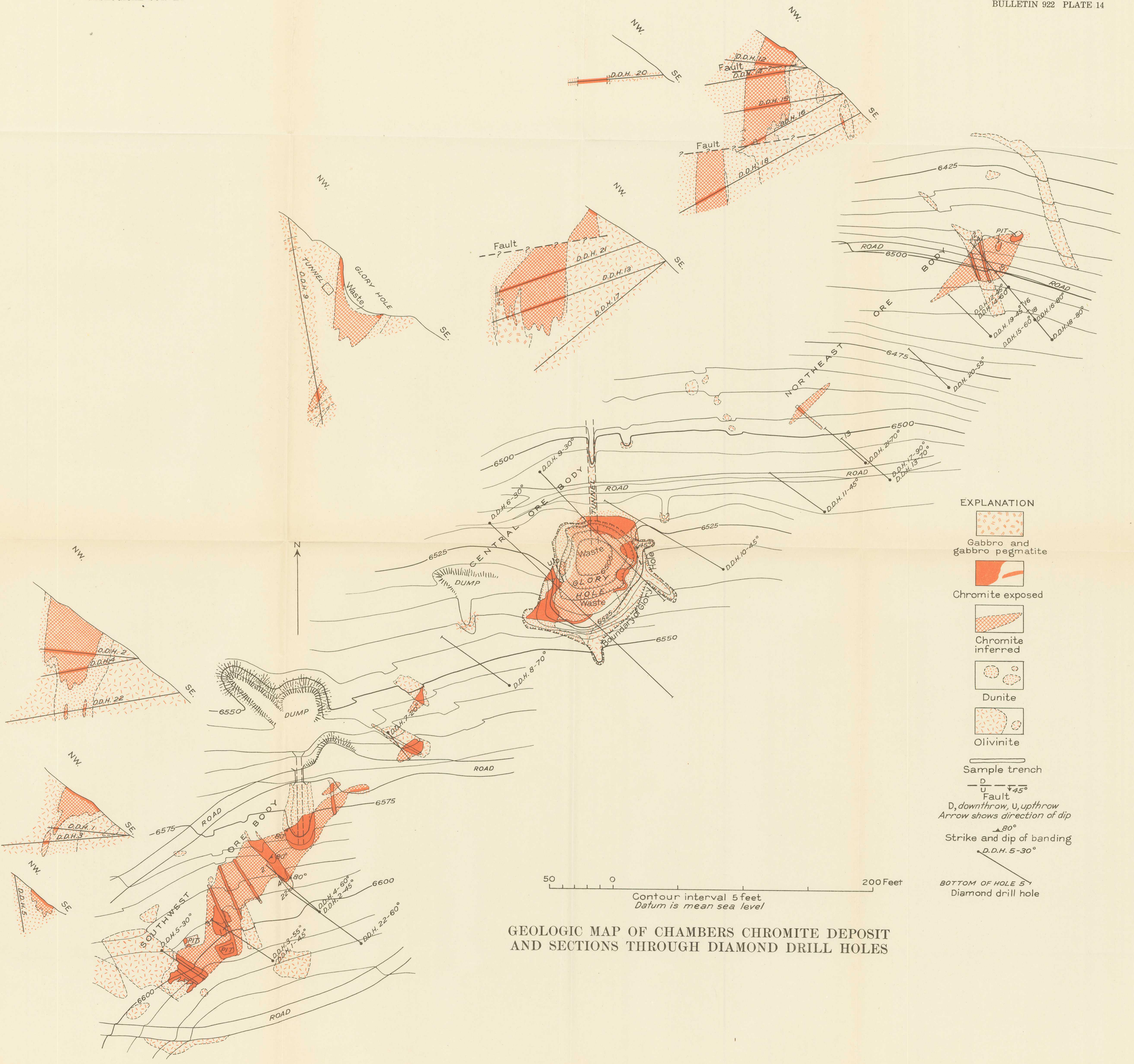




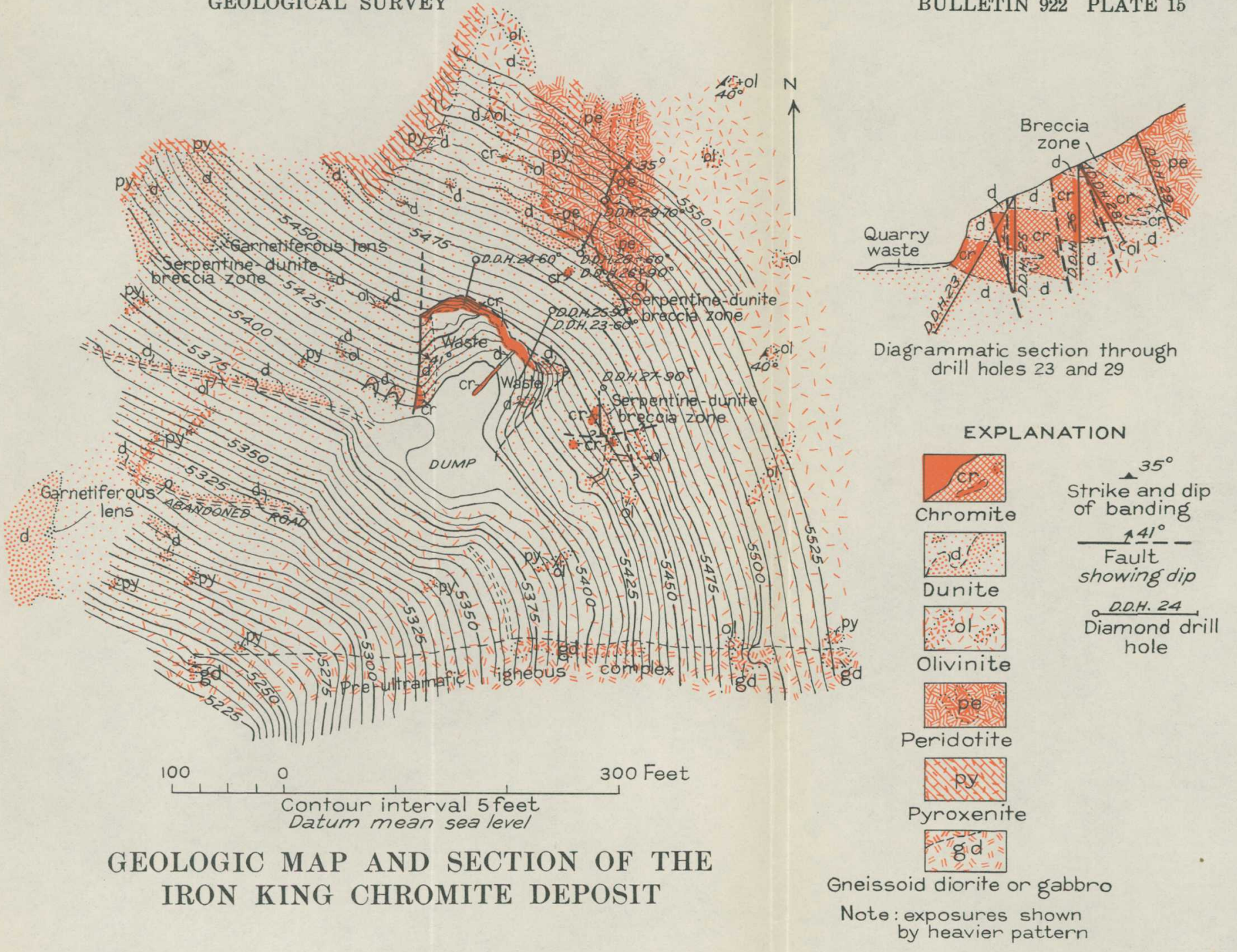


The ore in the Dry Camp deposit consists of spotted chromite in a matrix of serpentinized dunite and shows the most perfect planar banding seen in the district. The general relations and extent of the deposits are shown on plate 17. The mine was f1rst worked in september 1917, and the first ore was shipped two months later. Shipments to July 31, 1918, are reported as 300 tons of ore contalining 40 to 42 percent of chromic oxide

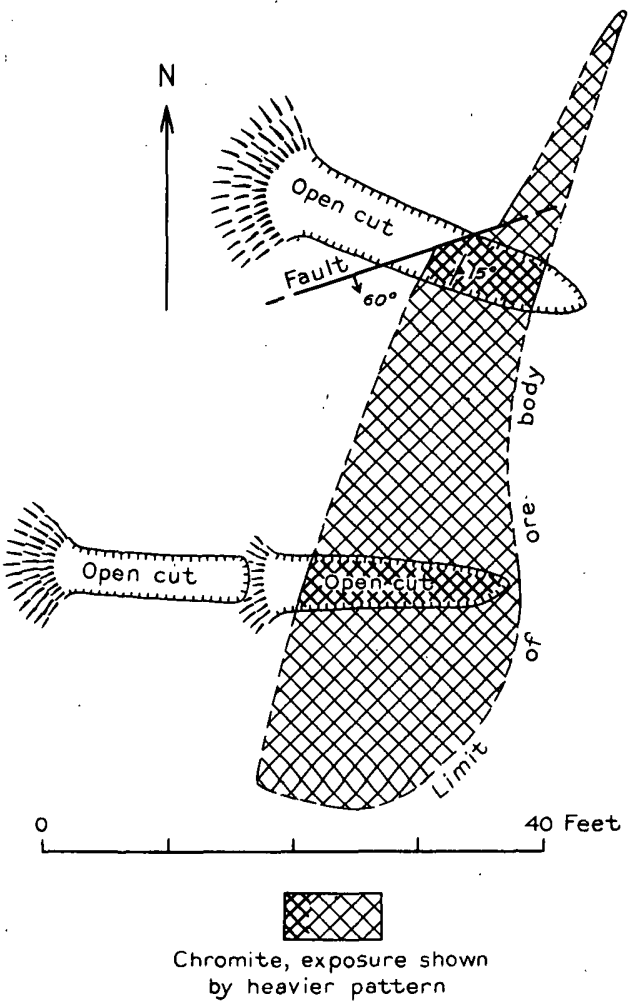

Plgure 15.--Plan of Black Velvet chromite deposit showing attitude of chrome body and contact relations.

and 63 tons of 35-percent ore; 100 tons of mine-run ore was shipped late in 1939 for concentration tests. Although the banding in the two deposits dips $45^{\circ}$ to $75^{\circ} \mathrm{SE}$., the deposits are very shallow. As shown in the sections, no ore was found in any of the diamond drill holes. Test pits in the lower deposit were sunk 8 feet in broken ore, and the exposed thickness 
of ore in the upper deposit is about 20 feet. The tenor of the ore 1s between 15 and 30 percent of chromic oxide, which is considerably below that of past shipments taken from the rich central part of the upper deposit.

Marks \& Thompson mine (27).--The Marks \& Thompson mine is In the northern part of the sW sec. 10, T. 14 S., R. 33 E., about 300 feet above Indian Creek. The mine was operated from November 1916 to August 1.917, and 400 tons of 30-percent chromic oxide ore was shipped.

The workings and general relations of the ore body are shown in plate 18. The ore consists of rather low grade spotted chromite in which both planar and linear banding are developed parallel to the walls of the ore body, which dip $40^{\circ}$ to $50^{\circ} \mathrm{SE}$. At contacts that are not fault contacts the ore grades abruptly into the olivinite country rock. Although three promInent faults cut the ore body, the ore is comparatively massive The entire surface extent of the chromite body is not exposed, and ore mey extend some distance beyond the northwestern side of the open cut. If movement on the northern transverse fault were normal, so that the northern segment of the ore body was dropped, the total reserve may be several thousand tons. The southern end of the mine appears to be worked out. The chromite in the trenches to the northeast is much faulted and is noteworthy mainly in that it shows that other chromite deposits of minable size may be present. The average tenor of the ore 1s probably between 15 and 25 percent of chromic oxide.

Ray mine (39).--The Ray mine is on the east end of Bald Mountain, at an altitude of 6,950 feet, about 2,000 feet a little west of north from the southeast corner of sec. $20, T$. 14 S., R. 33 E. The mine 1817 miles from John Day by road, 4 
miles of which is very steep and rough. The deposit was discovered in May 1918, and some ore was shipped. Westgate reports that the ore assayed 32 to 44.70 percent of chromic ox-. $1 \mathrm{do} .13$

The workings and the exposures of the chromite remaining in the mine are shown on plate 19. The ore body that Westgate described has been mined out except for small masses of low-grade spotted ore, which shows some banding. The chromite is surrounded by a dunite shell, and the country rock is jointed olivinite. The tunnel penetrates about 20 feet of crushed chromite, which may or may not be continuous with the small chromite lens over the tunnel. No ore is exposed in the two prospect pits northwest of the Ray mine.

A jax mine (54).--The A jax mine is in the SE⿺ sec. 16, T. 14 S., R. 33 E., 1,000 feet above Indian Creek. The workings consist of three open cuts about 25 feet long and 40 feet apart. The chromite occurs in several lenses that range in size from 2 by 3 by 4 feet to 3 by 15 by 12 feet and are arranged in echelon in a narrow dunite zone in olivinite, the long axes of the lenses being parallel to the dunite contacts. The ore includes spotted and nodular types in which consplcuous inear banding has been produced by fracturing and elongation of the chromite nodules. The spotted ore, particularly in the southernmost cut, fingers out into the dunite in a series of irregular cones extending parallel to the linear banding, which trends N. $80^{\circ} \mathrm{E}$. and pitches about $50^{\circ} \mathrm{E}$. The ore on the dump is reported to contain 35 to 41 percent of chromic oxide.

13/ Westgate, L. G., op. cit., p. 42. 
Bald Eagle deposit (53).--The Bald Eagle deposit 1s 1,000 feet northwest of the Chambers mine, at a 6,100-foot altitude, in the NEt sw $\frac{1}{4}$ sec. 13, T. 14 S., R. $32 \mathrm{E}$. The workings and general geologic relations are shown in figure 16. The chromite occurs in banded, spotted, and nodular ore, in which the nodules average three-elghths of an inch in length and about threosixteenths of an inch in thickness. The south end of the ore body, although badly shattered, is clearly intrusive into an

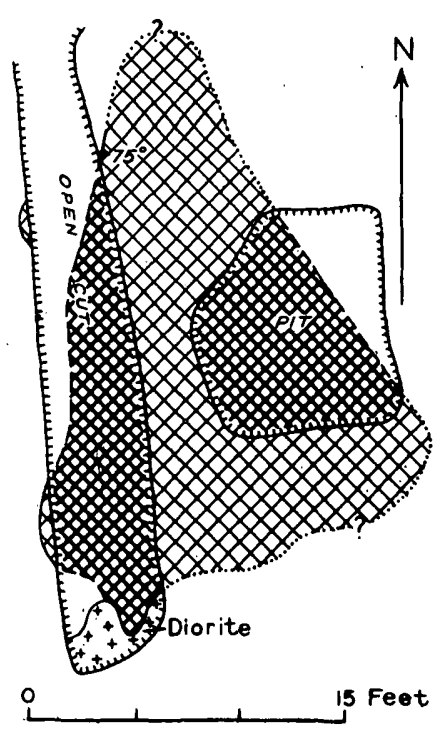

Figure 16.--Plan of Bald Bagle chromite deposit. inclusion of diorite that belongs to the basement complex. The banding in the chromite is essentially perpendicular to the diorite contact, and the fuxtaposition of the chromite body and the inclusion seems accidental. The contacts of dunite and ore show abrupt transitions; the surrounding country rock is ol1vinite. The average exposed thickness of ore is about 5 feet, and the ore appears to be of good milling grade.

$$
\text { Celebration mine (52) --The }
$$

Celebration mine is about 500

feet south of the East Fork of

Pine Creek, in the northwest corner of sec. 30, T. 14 S., R. 33 E. The workings and exposures of chromite are shown in figure 17. The country rock is dunite; largely altered to serpentine, which a short distance to the west is intimately mixed with banded gabbro. The ore is highgrade nodular chromite in which equidimensional thch nodules 
of chromite occur in a matrix of fresh green monocilnic pyroxene. The ore averages about 5 feet in thickness and is considerably broken; the tunnel follows a shatter zone that dips about $20^{\circ}$ S. paraliel to the ore body.
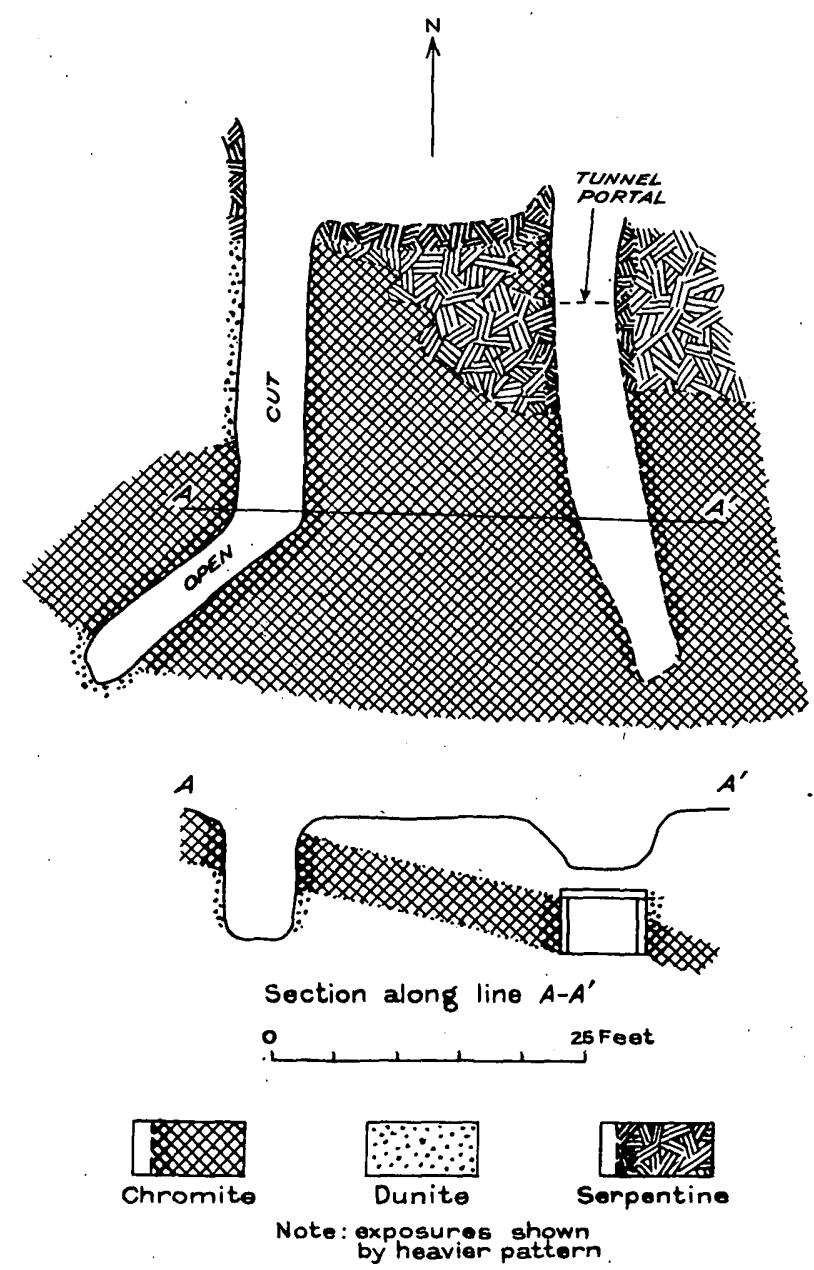

Figure 17.--Plan and section of Celobration mine.

Ward mine (28).--The Ward, Kingsley (30), Howard (26), Powers (2I), and Big Bertha No. 1 (40) mines and the deposits west of Pine Creek (58) are similar in that the chromite occurs in thin tabular bodies or irregular stringers that appear to be schlieren. 
The Ward mine is in the SE $\frac{1}{4}$ sec. 5, T. 14 S., R. 32 E., about a third of a mile west of Dog Creek. The deposit was first worked in 1916 and was mined out late in 1918. Total production was between 2,000 and 2,500 tons. About a quarter of this was high-grade black ore averaging between 38 and 45 percent of chromic oxide in carload lots; the remainder averaged 31 to 32 percent chromic oxide. Massive black ore, spotted ore, and nodular ore were present. The relations between nodular ore, spotted ore, and barren dunite are shown in flgure 12. The ore body was a vertical mass about 80 feet long, 70 feet deep, and not more than 10 feet thick. The east end was faulted off against olivinite, and the west end pinched and faded out into barren dunite. The remaining ore in the mine shows well-developed vertical planar banding parallel to the walls. Where exposed in a cross-cut trench the spotted ore at the north edge of the ore body grades into 8 feet of barren dunite, which in turn grades into vertically banded olivinite. Evidence of post-chromite pegmatitic activity is reverled by dump specimens that contain brecclated chromite enclosed in very coarse grained pyroxene.

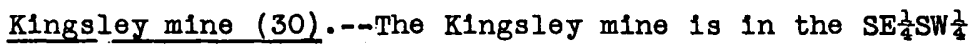
sec. 9, T. 14 S., R. $32 \mathrm{E}$,, in the headwaters of Dog Creok, about 5,300 feet above sea level. The mine was operated from November 1, 1917, to November 1919. The 200 tons of ore shipped In 1918 averaged 45 percent of chromic oxide; some assays are reported to have run as high as 49.78 percent. The ore consists of black to spotted chromite and forms irregular bunchy stringers, from a few inches to 5 feet wide, in a dunite zone in olivinite. The stringers, which are essentially parallel,strike N. $50^{\circ} \mathrm{W}$, and dip $60^{\circ} \mathrm{NE}$. The zone has been explored about 100 feet along the strike and 35 feet vertically by an open cut and four tunnels. Imperfectly banded spotted ore was found in a prospect pit 50 feet southwest of the main workings. 


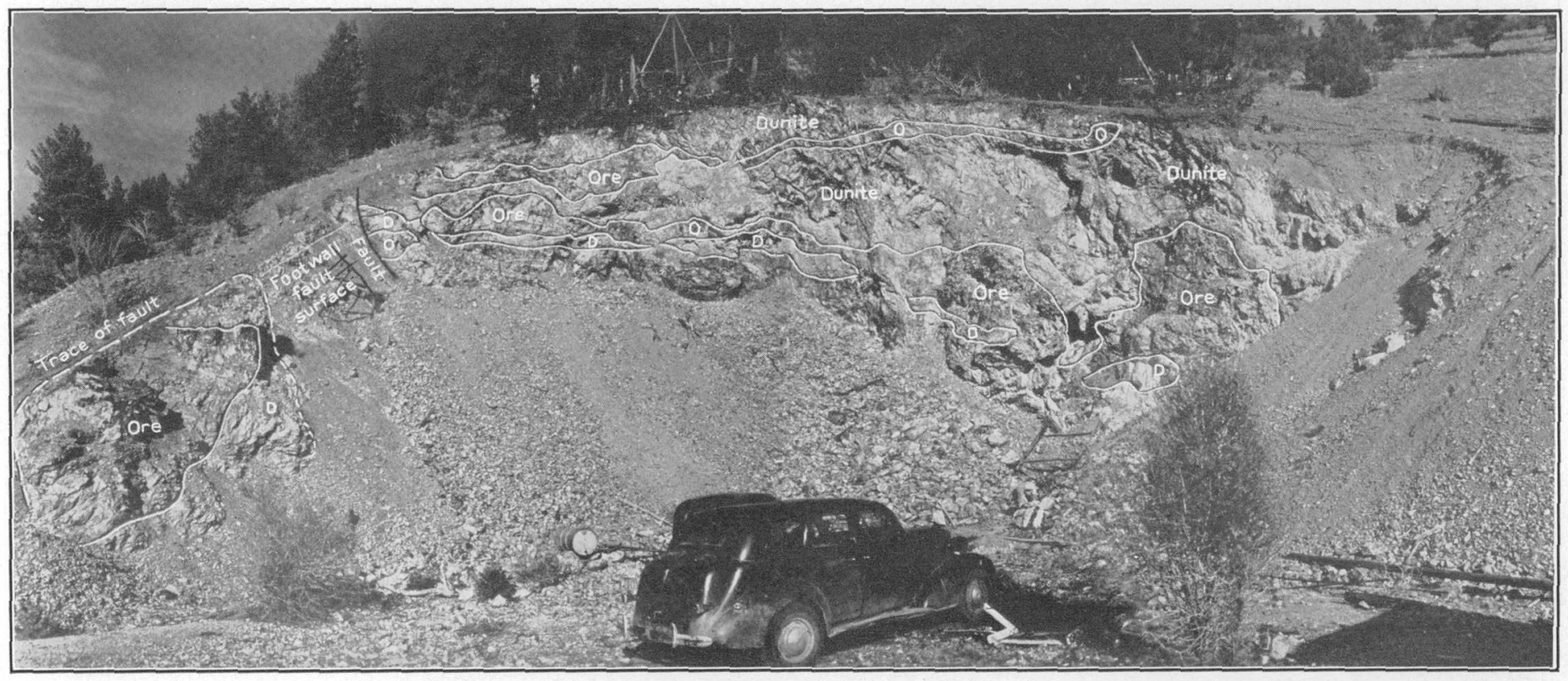

VIEW OF QUARRY AT IRON KING MINE.

Shows the footwall fault and the distribution of ore in the face. The drilling rigs are set up at drill holes 24 and 25. 
Powers mine (21).--The Powers mine is on the ridge west of Dog Creek, near the middle of the west edge of sec. 4, T. 14 S., R. 32 E. The mine was in operation from January. 1917 to August 1918, and a total of about 480 tons of ore containing 40 percent or more of chromlc oxlde was shlpped. The ore consisted of about equal parts of high-grade massive chromite containing about 50 percent of chromic oxide and low-grade spotted ore averaging 25 to 30 percent. The workings, which consist of a series of trenches and open cuts and two tunnels, all on the east slope of the ridge, extend over a horizontal distance of 250 feet and have a vertical range of 50 or 60 feet. The chromite-bearing zone is irregular in thickness, its thickest part belng 8 feet wide and its avergge about 3 feet. The chromite occurs in a dunite band that is little wider than the chromite body. The ore and dunite trend N. $50^{\circ} \mathrm{W}$. and dip $60^{\circ}$ or more southward. Planar banding is well-developed parallel to the walls. At the northwest end of the deposit the chromite grains string out into dunite and olivinite. A smali amount of fresh enstatite was found in some of the ore.

Howard prospects (26) --The Howard prospects are 3,500 feet northeast of the Dry Camp mine, near the center of sec. 8, T. 14 S., R. 33 E. The upper of the two principal prospects is a T-shaped open cut with the bottom of the T pointing northward. Small lenses of massive chromite and irregular masses of pyroxene occur in partly sheared and serpentinized dunite. Most of the ore contacts are faulted. The lower opening is a 75-foot trench along a chromite body trending $\mathrm{N}$. $25^{\circ} \mathrm{W}$. The main part of the cut is 35 feet long, 4 to 12 feet wide, and 10 feet deep. The ore forms a veinlike stringer of spotted and massive chromite in an irregular body of dunite, which grades into the 
olivinite country rock. The distribution of chromite in the ore and of pyroxene in the olivinite suggest linear banding and are remarkably similar. About 10 tons of low-grade ore is on the dump.

Prospects west of Pine Creek (58) -- The prospect pits west

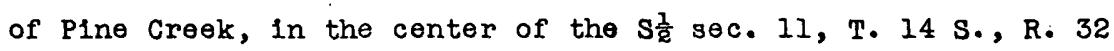
E., reveal small chromite bodies enclosed in a lens of unsheared dunite, which is nearly 2,000 feet 1 ong and 200 to 400 feet wide. The dunite is itself enclosed in olivinite. The contacts between the two rocks are rather well exposed and indicate that the dunite strikes northwestward and dips $20^{\circ}$ to $30^{\circ} \mathrm{NE}$. The chromite forms only smail irregular lenses, and no minable ore is exposed. The outstanding feature of the deposits is a band of spotted chromite between one-half inch and 3 inches thick, which is exposed near the upper end of the dunite mass. This chromite band is traceable continuously on a vertical rock face for upwards of 40 feet and was followed for nearly 35 feet in a tunnel at right angles to the rock face. The chromite iles parallel to the contacts of the dunite mass and apperently is a schlierenlike body whose lateral extent is great in comparison with its thicknoss.

Sheep Rock deposits (37, 40).--Three chromite deposits on Sheep Rock, in prospects called the Hanenkrat, Morgan, and Campbell, were described by Westgate, 14 but because of mining since Westgate's visit, there is some difficulty in fitting his descriptions to the present prospects. The Hanenkrat (40) prospect has been renamed the Big Bertha No. 1; the Morgan and Campbell prospects were not definitely ldentified.

The Big Bertha (37) deposit may be the same as the Campbell claim of Westgate. The ore is exposed in on open cut about 20 feet long, 10 feet wide, and 5 feet deep. The ore is low grade, 
UNITED STATES DEPARTMENT OF THE INTERIOR GEOLOGICAL SURVEY

\section{EXPLANATION}

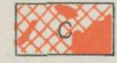

Chromite

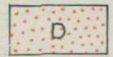

Dunite

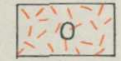

Olivinite

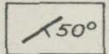

Dip of fault

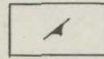

Dip of banding in chromite

Note: chromite exposure shown in solid color

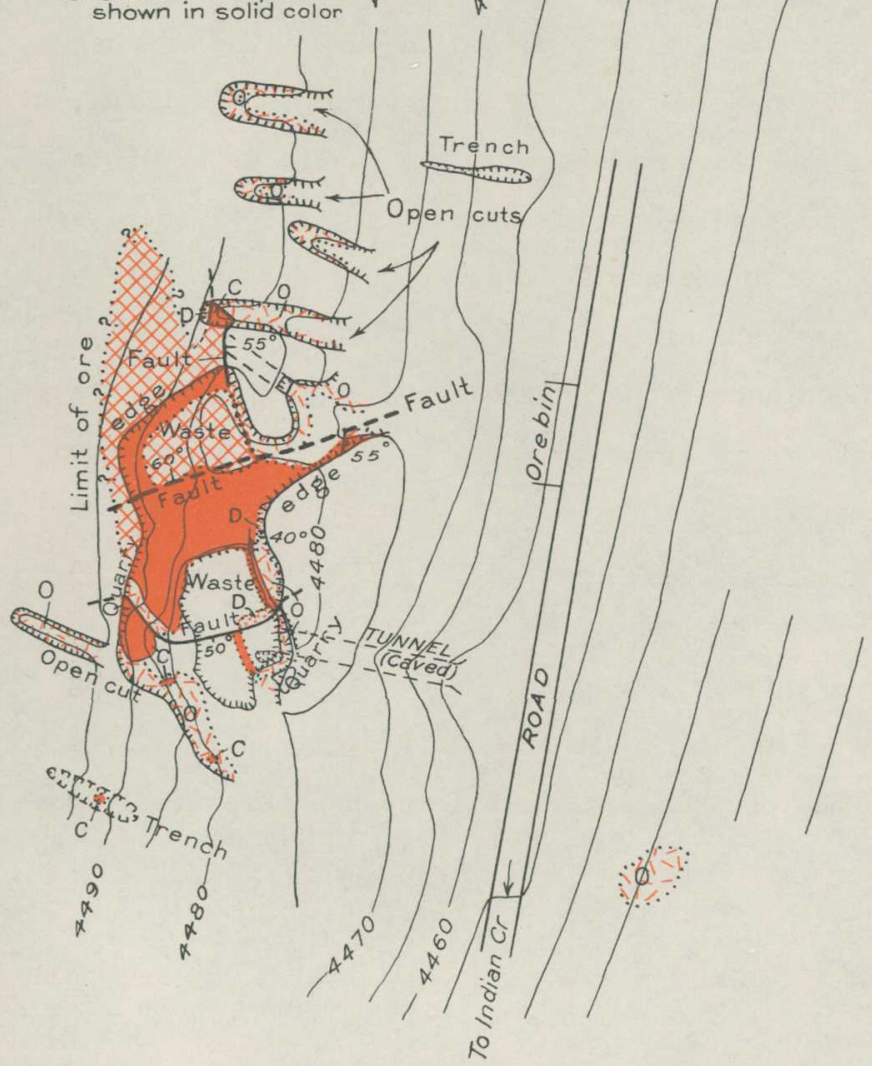

0
6
$\alpha$
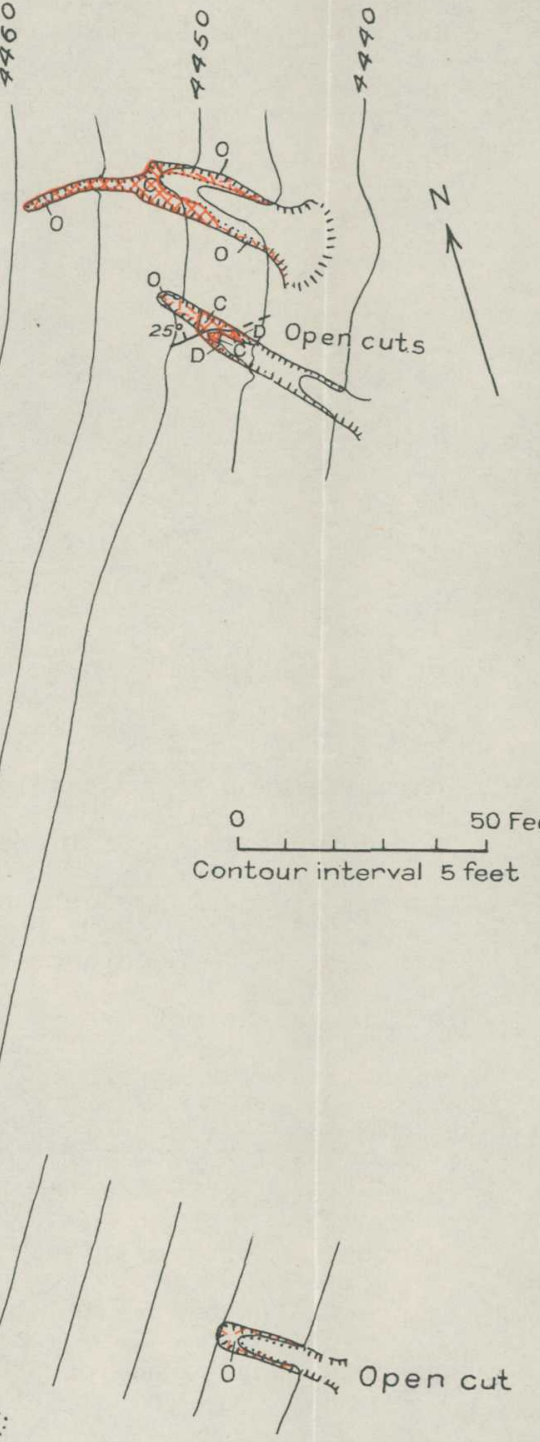

GEOLOGIC MAP OF THE MARKS THOMPSON CHROMITE DEPOSIT 
UNITED STATES DEPARTMENT OF THE INTERIOR GEOLOGICAL SURVEY

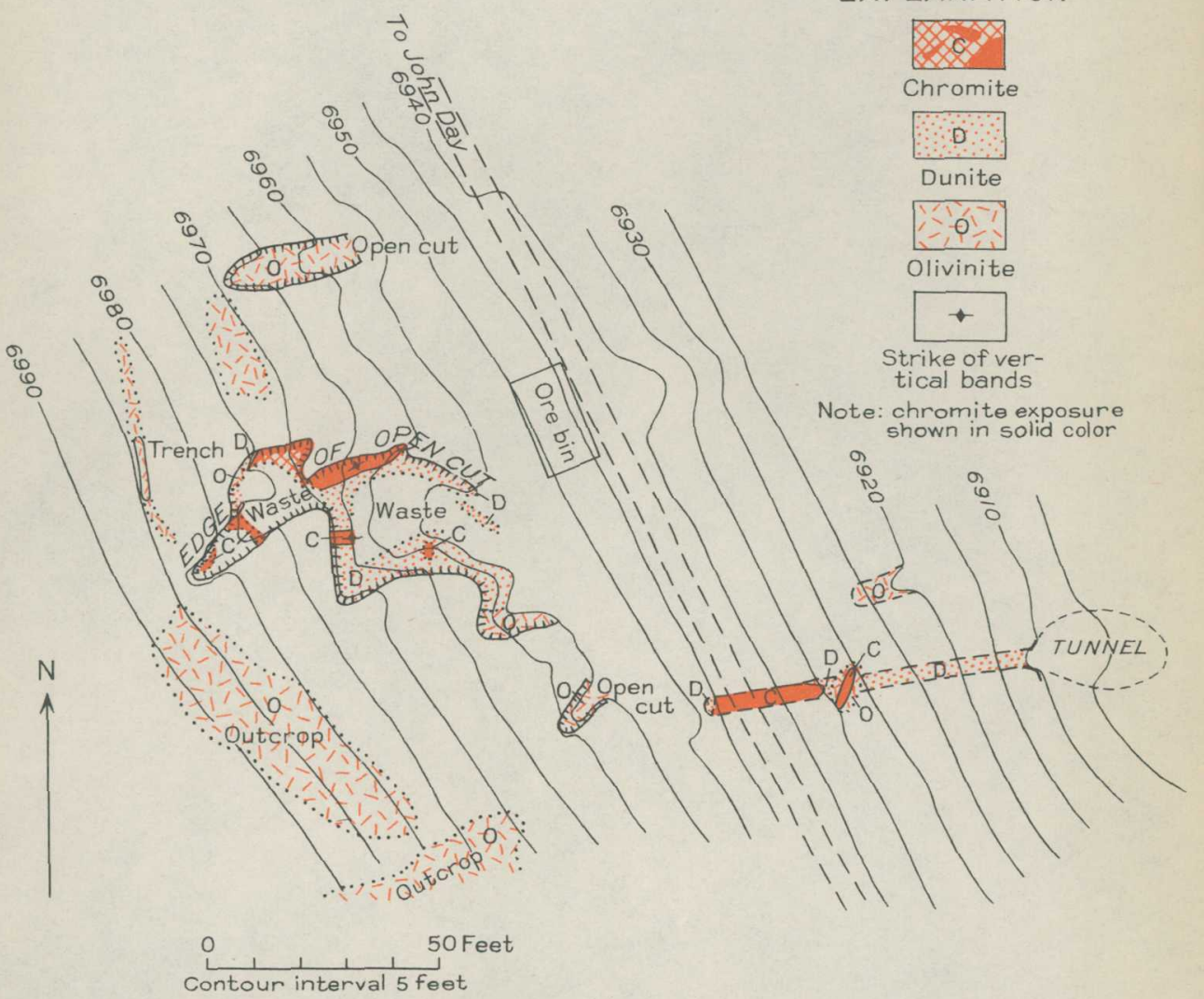

PLAN OF THE RAY MINE
BULLETIN 922 PLATE 19

\section{EXPLANATION}

Chromite

Note: chromite exposure shown in solid color
Dunite

$\underbrace{0}_{\text {Contour interval }} \frac{1}{5 \text { feet }}$ 
1s spotted, and shows distinct vertical linear banding combined with planar banding striking $N .60^{\circ}$ E. The chromite is in dunite, and although the planar bands feather out lengthwise, the lateral contacts are commonly well defined. In small 1rregular bunches and stringers of higher-grade chromite that occur outside of the main body of spotted ore, only vertical Iinear structure is apparent.

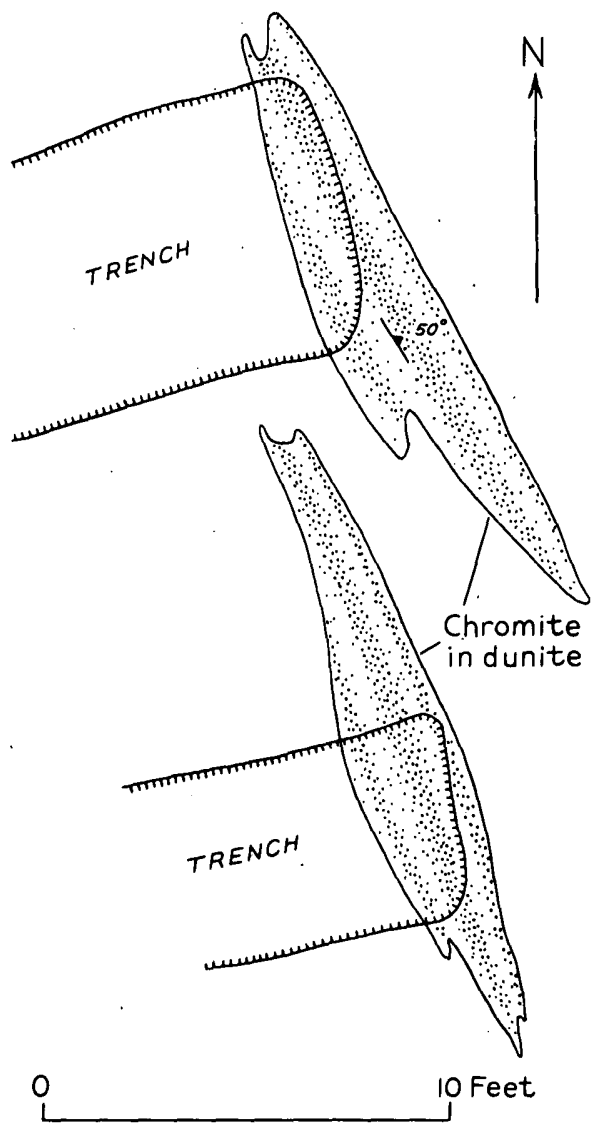

Figure 18.--Plan of Ray chromite prospects between Overholt and Indian Creoks showing attitude of banding. The country rock is olivinite.

Ray prospects $(55,56)$---Several prospect plts have been dug in small chromite lenses in the west fork of Overholt Creok

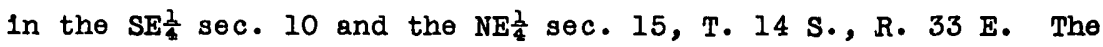
relations of the two largest lenses, which are in sec. 10, are shown in figure 18. The ore is well-banded, partly massive and 
partly spotted. It is enclosed in dunite, which grades into olivinite within a fow inches from the ore. The other lenses that have been prospected are much smaller. The average tenor In chromic oxide is probably about 20 percent.

Reed (13) and Campbell mines (14).--The Reed and Campbell

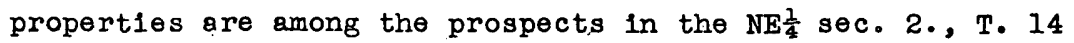
S., R. 32 E., and are indicated on plate 12 by the number (59). The openings are now slumped, and the only visible ore occurs in two 1-inch stringers of spotted chromite in dunite and ol1vInite at the Campbell prospect.

\section{Deposits in serpentine}

Canyon City-Mount Vernon belt

Silver Lease mine (10).--The Silver Lease mine is about 3 miles northwest of John Day near the middle of the west edge of sec. 17, T. 13 s., R. 31 E. The workings and the distribution of the ore are shown on plate 20. About 700 tons of ore averaging 28 percent of chromic oxide is reported to have been shipped in 1918. The ore consists of lenses of dark spotted chromite bounded by slickensided contacts against serpentine. The serpentine contains pyroxene and is probably âltered olivinite. The ore remaining in the glory hole consists only of small lenses and a shell of chromite perhaps 3 feet thick that lies against the gabbro (?) dike. The main ore block is west of the gabbro (?), which evidently cut squarely across the original chromite lens.

Norway (20) and Smith \& Geltsfleld mines (18) and prospect (60).-The Norway and Smith \& Geltsfield mines, in the NW $\frac{1}{4}$ sec. 3, T. 14 S., R. 31 E., were described by Westgate, but the lode deposits on the Norway ground had not been mined at the time of his visit. 
UNITED STATES DEPARTMENT OF THE INTERIOR
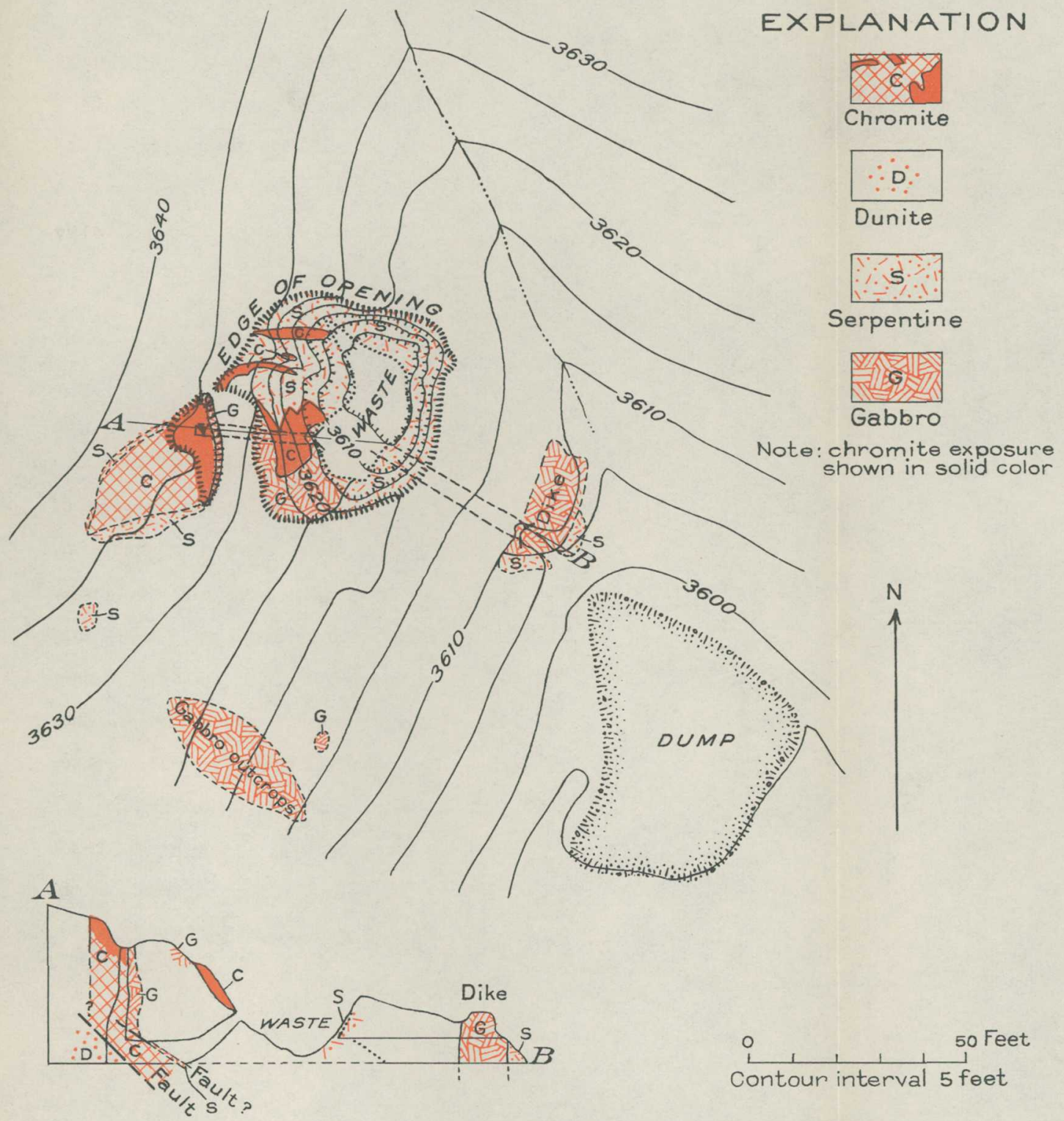

PLAN AND CROSS SECTION OF THE SILVER LEASE CHROMITE DEPOSIT 
The Sm1th \& Ge1tsfield produced 48 tons of 35-percent chrome ore in 1917, and the Norway mine produced 922 tons of ore containing more than 40 percent of chromic oxide $\left(\mathrm{Cr}_{2} \mathrm{O}_{3}\right)$ in 1918. Four principal bedrock deposits were mined at the Norway, the largest of which is shown in figure 19. The ore ranges from massive high-grade to spotted low-grade chromite and includes some nodular ore. The chromite contacts are slickensided, and In one opening the chromite is sheared out in small lenses along

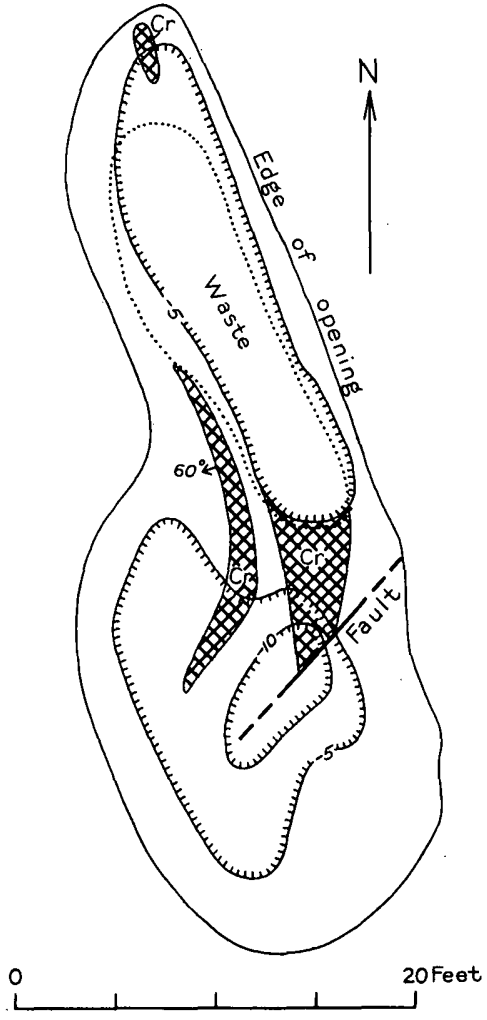

Figure 19.--Plan of principel opening on Norwas claim. Cr, chromite. a fault zone. The dumps contain about 400 tons of $10 w-g r a d e$ ore averaging 15 to 25 percent of chromic oxide and about 10 tons of higher-grade ore probably averaging 35 percent of chromic oxide.' Not more than 50 tons of ore is visible in the ground. At the prospect (60) southwest of the Norway, in the NEt sec. 8, two shafts were sunk 25 feet apart along a shear zone in pale-green serpentine. The zone trends $\mathrm{N} .75^{\circ} \mathrm{E}$. and dips $60^{\circ} \mathrm{s}$. Spotted chromite is found on the dump as thin flaky pieces as much as half an inch thick, and It is inferred that the ore occured in thin irregular bands, possibly as schlieren.

Murderers Creek belt

Glasscock cla1ms $(15,16,17) \cdot-$ The Uncle Sam (15), Queen of the May (16), and stone \& Hankins (17) mines, collectively

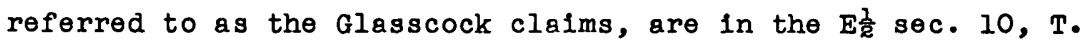


14 S., R. 28 E., about $1 \frac{1}{2}$ miles west of Flelds Creek. The workings are caved and all the deposits are reported to be mined out, except possibly. the stone \& Hankins, which is now held by Roy Glasscock as the Another Chance claim. The Uncle Sam and Queen of the May deposits, which are in dense serpentine derived from dunite and olivinite, produced about 40 and 80 tons, respectively, of ore containing more than 40 percent of chromic oxide. The stione \& Hankins mine produced about 300 tons of ore that averaged slightly more than 40 percent of chromic oxide and ran as high as 45 percent. Boulders of high-grade ore are exposed in small cuts near the stone \& Hankins workings, although no sizable bodies were found in place.

Hankins (Spring and Chrome Ridge) mine (45).--The Hankins mine, described by Allen as the spring and Chrome Ridge mine,

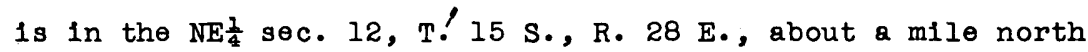
of Murders Creek on the crest of the divide west of Oregon Mine Creek. About 65 tons of high-grade ore was shipped in 1918. The ore consists of massive black chromite that occurs in small lenses with slickensided contacts agalnst the enclosing dense dunitic serpentine. The main body of serpentine is somewhat pyroxenic and probably derived from olivinite. No minable ore was seen.

Delore prospects (47).--The Delore prospects are on a bare serpentine ridge between Deer Creek and the South Fork of Mur-

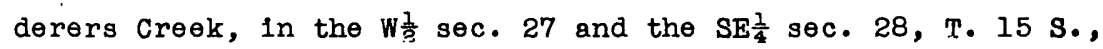
R. 28 E. Total shipments amounted to about 50 tons of ore, sald to average 54 percent of chromic oxide. The commercial chromite occurs as small sheared lenses in the serpentine. In the lowest cut, fine-grained brown chromite coatings on slickensided surfaces in the serpentine are unusually prominent. The workings include seven open cuts on the northwest side of 
the ridge, in sec. 27, and one cut on the southeast side of the same ridge, in sec. 28, where the only ore in place was seen. Here a lens of dense black chromite 3 feet long and 8 inches in greatest thickness trends $\mathrm{N} .15^{\circ} \mathrm{E}$. and stands vertical in serpentine. This ore is somewhat magnet1c and contains about 21 percent of 1ron.

Prospects near Bull Spring (61).--Three prospects are situated in the vicinity of Bull Spring, which is near the common corner of secs. 15, 16, 21, 22, T. 15 S., R. 28. E. The worklngs are in the serpentine that forms a bare ridge northwest of the road between Murderers Creek and the South Fork of Murderers Creek. No chromite besides that forming thin coatings on slickenslded surfaces was seen in place, although a few small pleces of slickensided black ore were found on the dumps. 
The use of the subjoined mailing label to return this report will be official business, and no postage stamps will be required

\author{
UNITED STATES \\ DEPARTMENT OF THE INTERIOR \\ GEOLOGICAL SURVEY \\ OFFICIAL BUSINESS \\ This label can be used only for returning \\ official publications. The address must not \\ be changed.
}

\title{
GEOLOGICAL SURVEY,
}

